\title{
Flue gas desulfurization gypsum and grass buffer strip influence on runoff and nutrient loss from inorganically and organically fertilized corn on a US Coastal Plain soil
}

\author{
D.M. Endale, T.C. Strickland, H.H. Schomberg, D.D. Bosch, O. Pisani, and A.W. Coffin
}

\begin{abstract}
Broiler litter (BL) and flue gas desulfurization gypsum (FGDG), both readily available in the US Southeast, can potentially ameliorate soil constraints adversely affecting agricultural productivity and environmental quality in the region. However, benefits and risks must be evaluated prior to making recommendations to producers. The effectiveness of a combination of FGDG and grass buffer strips (GBS) to reduce edge-of-field nutrient losses from corn (Zea mays L.) production under inorganic (NPK) or organic (BL) fertilization was evaluated on Coastal Plain soils near Tifton, Georgia, from April of 2014 through January of 2017. Nine treatments were randomly established in each of three replications on plots instrumented to collect runoff. This was the first phase of a three-phase study. Treatments consisted of combinations of three fertilizer treatments (NPK, BL, and BL+FGDG) and three GBS treatments (no GBS [-GBS], GBS without FGDG [GBS-FGDG], and GBS with FGDG [GBS+FGDG]). A tenth treatment of NPK+FGDG without GBS was also included. Annual rates for BL and FGDG were $13.45 \mathrm{Mg} \mathrm{ha}^{-1}$ each. The BL rate was based on a high nitrogen $(\mathrm{N})$ demand of corn and would represent a risky scenario for nutrient loss. Runoff and concentrations and loads of nitrate-nitrogen $\left(\mathrm{NO}_{3}-\mathrm{N}\right)$, ammonium-nitrogen $\left(\mathrm{NH}_{4}-\mathrm{N}\right)$, total Kjeldahl nitrogen (TKN), dissolved reactive phosphorus (DRP), and total P (TP) were determined in runoff from 29 storms from May of 2015, through January of 2017. Rainfall partitioned into runoff (percentage runoff) decreased by $50 \%$ to $70 \%$ under -GBS with BL or BL+FGDG compared with NPK fertilization, and under GBS-FGDG or GBS+FGDG compared with -GBS for NPK and BL fertilization. Under -GBS, concentration of DRP and TP increased by $\sim 160 \%$ from BL compared with NPK fertilization, and by $150 \%$ for DRP and by $115 \%$ for TP from BL+FGDG compared with NPK fertilization. On the other hand, the combined BL+FGDG and GBS+FGDG treatment reduced nutrient concentration by $65 \%$ to $80 \%$ compared with BL with -GBS (a standard practice), and nutrient load by $40 \%$ to $70 \%$ compared with NPK with -GBS (another standard practice) or BL with -GBS. Results indicate the potential for FGDG to improve edge-of-field runoff water quality when applied to fields with BL and to edge-of-field GBS. In planned follow-up articles, results will be compared with phase-2 when BL and FGDG rates were reduced by a third and phase-3 when BL application was discontinued.
\end{abstract}

Key words: eutrophication—manure—phosphorus—poultry—soil amendment—water quality

Poultry production and coal-fired power generation both produce byproducts that can have beneficial uses in agricultural production systems. In $2017,57.1 \%$ of the 8.91 billion broilers raised in the United

Received September 15, 2020; Revised April 8, 2021; Accepted April 20, 2021; Published online July $26,2021$. total excrement, spilt feed and water, feathers, soil, and bedding material such as wood shavings, sawdust, wheat straw, peanut hulls, etc.) containing $185,000 \mathrm{Mg}$ of total nitrogen $(\mathrm{N})$, $68,000 \mathrm{Mg}$ of elemental phosphorous $(\mathrm{P})$, and $115,000 \mathrm{Mg}$ of elemental potassium $(\mathrm{K})$ are produced annually in the five states combined. Values could be $30 \%$ greater based on estimation approaches of Mitchell and Tu (2005) or Ashworth et al. (2019). Most plant macro- and micronutrients are present in BL depending on types of feed, supplement, and enzymes (Ashworth et al. 2019; Tewolde et al. 2005). Numerous studies indicate that soil amendment with organic materials such as BL could improve soil organic matter and consequently soil physical and chemical properties (Feng et al. 2019, 2021; Adeli et al. 2007, 2010; Eden et al. 2017; Edmeades 2003; Sistani et al. 2004; Watts et al. 2010).

Forages and crops normally require fourto eight-fold more $\mathrm{N}$ than $\mathrm{P}$, while $\mathrm{BL}$ has 1:1 to $3: 2$ total $\mathrm{N}$ :phosphorus pentoxide $\left(\mathrm{P}_{2} \mathrm{O}_{5}\right)$ ratio (Zhang et al. 2002; Ashworth et al. 2019). Hence, using $\mathrm{BL}$ to meet the $\mathrm{N}$ needs of forages and crops results in overapplication of $\mathrm{P}$ and excessive $\mathrm{P}$ levels in soils (Schomberg et al. 2009; Kingery et al. 1994), which can cause nonpoint source pollution of surface waters (Sharpley et al. 2017; Carpenter et al. 1998; Moore et al. 1995). Heavy metals such as arsenic (As), cadmium $(\mathrm{Cd})$, copper $(\mathrm{Cu})$, and zinc $(\mathrm{Zn})$, often present in BL, can contaminate soil and surface waters and reach toxic levels for certain crops (Hou et al. 2014; Endale et al. 2010; He et al. 2009). Pastures and hay lands near broiler production facilities typically receive repeated $\mathrm{BL}$ application, exacerbating buildup of potentially environmentally harmful nutrients.

Coal-fired power plants in the United States produced $421.44 \mathrm{Tg}$ of flue gas desul-

Dinku M. Endale (corresponding author) is an agricultural engineer/hydrologist, and Timothy C. Strickland is the research leader with the USDA Agricultural Research Service (ARS), Southeast Watershed Research Laboratory (SEWRL) in Tifton, Georgia. Harry H. Schomberg is a research plant physiologist/ecologist with the USDA ARS, Beltsville Agricultural Research Center, Sustainable Agricultural Systems Laboratory in Beltsville, Maryland. David D. Bosch is a research hydraulic engineer, Oliva Pisani is a research chemist, and Alisa $W$. Coffin is a research ecologist with the USDA ARS, SEWRL in Tifton, Georgia. 
furization gypsum (FGDG; calcium sulfate dihydrate, $\mathrm{CaSO}_{4} \cdot 2 \mathrm{H}_{2} \mathrm{O}$ ) from 2000 to 2018 (American Coal Ash Association 2021) as a byproduct of "scrubbing" sulfur dioxide $\left(\mathrm{SO}_{2}\right)$ from flue gases to meet air quality regulations (EPRI 2006; Kairies et al. 2006). The FGDG currently produced is of high purity with low levels of toxic components (Schomberg et al. 2018; Chen and Dick 2011; EPRI 2011; Koralegedara et al. 2019). Average FGDG production from 2014 to 2018 was $29.8 \mathrm{Tg} \mathrm{y}^{-1}$ (Good and VanBriesen 2019; Southern Company 2017, 2018). From 2000 to $2018,51.1 \%$ of the FGDG produced was used in construction industries for wallboard, concrete and cement mixes, structural fill in embankments, and mining, while only about $2.3 \%$ was used in agriculture as a soil amendment. The remaining $196.4 \mathrm{Tg}$ of FGDG was placed in landfills near production facilities.

Although gypsum has been used as a soil amendment for a long time, availability, quality, and industrial demand has limited its widespread use in agriculture (Chen and Dick 2011; Crocker 1922). The literature indicates agronomic, soil health, and water quality benefits of gypsum in many but not all soils and production systems (Shainberg et al. 1989). As a moderately soluble source of calcium (Ca) and sulfur (S), gypsum application is beneficial to a variety of crops (Chen and Dick 2011; Miller et al. 1998; Stout et al. 1998; Wallace 1994). Gypsum has been shown to improve soil aggregation, flocculation, and structural stability; reduce surface sealing and crusting; improve water infiltration and percolation; and reduce runoff and soil erosion (Norton and Dontsova 1998; Stout et al. 1998; Shainberg et al. 1989; Miller 1988). Several studies point to reduction of water-soluble $\mathrm{P}$ in runoff resulting from gypsum application (King et al. 2016; Endale et al. 2014b; Torbert and Watts 2014; Watts and Torbert 2009, 2016; Norton 2008; Stout et al. 1998).

Grass buffer strips (GBS) reduce nutrient $(\mathrm{N}$ and $\mathrm{P})$ transport from agricultural fields and are identified as best management practices by USDA Natural Resources Conservation Service (USDA NRCS 1999; Dillaha et al. 1989; Magette et al. 1989). However, site-specific conditions, such as cropping system, hydrology, climate, soil, type, and buffer width, determine effectiveness of GBS (Habibiandehkordi et al. 2019; Valkama et al. 2019; Stutter et al. 2012; Dorioz et al.2006). Data indicating increased effectiveness of GBS through FGDG amendment are limited. In one study, Watts and Torbert (2009) found that a $1.52 \mathrm{~m}$ wide GBS reduced soluble $\mathrm{P}$ concentrations in surface runoff from plots fertilized with BL by $32 \%$ to $40 \%$ and $18 \%$, with and without FGDG amendment, respectively. Their study applied concentrated flow $\left(124 \mathrm{~mm} \mathrm{~h}^{-1}\right.$ producing 30-minute runoff event) to tall fescue (Schedonorus arundinaceus) established on a sandy loam soil in the Appalachian Plateau region of northeast Alabama. Effectiveness of FGDG amendment to reduce nutrient loss with GBS on Coastal Plain soils of the US Southeast is unknown.

Ultisols and Alfisols are the predominant soil groups in the Southern Coastal Plain (West et al. 1997). Coastal Plain surface soils are mostly sandy, have low organic matter, are prone to surface crusting, have low water holding capacity, and are highly erodible. Intense spring and summer storms often result in runoff and loss of nutrients. Twenty years (1998 to 2019) of research at Tifton, Georgia, showed that surface runoff was 1.7fold and mean annual total sediment loss was 7.7-fold greater from conventional tillage (CT) than strip tillage (ST); carbon (C) and $\mathrm{N}$ losses from ST were less than from $\mathrm{CT}$ in part because of sediment-bound $\mathrm{C}$ and $\mathrm{N}$; and surface runoff was the primary avenue for loss of $\mathrm{P}, \mathrm{K}, \mathrm{Zn}$, iron (Fe), and manganese $(\mathrm{Mn})$, while subsurface flow was the primary avenue for loss of $\mathrm{Ca}$, magnesium $(\mathrm{Mg})$, and S (Pisani et al. 2020; Strickland et al. 2015; Endale et al. 2014a; Bosch et al 2012). Results from this long-term study for the period from 2004 to 2008 determined that subsurface flow was the primary hydrologic pathway for losses of dissolved $\mathrm{N}$ and chloride $(\mathrm{Cl})$ in both tillage systems (Bosch et al. 2015). The total five-year load for $\mathrm{N}$ was equivalent to $8.3 \%$ and $18.4 \%$ of the applied to CT and ST, respectively.

Our project was designed to evaluate the effectiveness of FGDG in reducing edgeof-field losses of nutrients from inorganic (NPK) or BL fertilization to corn (Zea mays L.) on Coastal Plain soils. In this evaluation, FGDG was applied on cropped areas and on bermudagrass (Cynodon dactylon L.) GBS located at the down slope field edge. Our hypothesis was that addition of FGDG to cropped areas will reduce nutrient losses significantly below that without FGDG and the effect would be greater for BL compared to NPK fertilization. We also hypothesized that application of FGDG to GBS would increase the effectiveness of the GBS. While the experiment was established in spring 2014, data for runoff quantity and quality were obtained beginning in 2015 to allow for complete establishment of the runoff collection system.

\section{Materials and Methods}

Site and Experimental Setup. The study has a nine-year duration divided into three phases of three years each. In phase-1 (the subject of this article), BL and FGDG were applied at $13.45 \mathrm{Mg} \mathrm{ha}^{-1} \mathrm{y}^{-1}$. In phase-2, rates are reduced to $4.48 \mathrm{Mg} \mathrm{ha}^{-1} \mathrm{y}^{-1}$. In phase-3, fertilization is all NPK (no BL) but FGDG rate continues at the same as that of phase2. Thus, the study is designed to track the hysteresis of nutrient dynamics in the soil, runoff, and plants from residual sources of $\mathrm{BL}$ and FGDG through the three phases. Our rationale for the rate during phase-1 included (1) a previous study indicating effectiveness of FGDG in reducing $\mathrm{P}$ losses in runoff is dependent on soil $\mathrm{P}$ levels - since $\mathrm{P}$ level in our soil was low, we wanted to increase it quickly; (2) typical BL application in the area is based on crop $\mathrm{N}$ requirement assuming 50\% mineralization during the cropping season; (3) because of transportation costs, BL tends to be applied frequently to nearby fields leading to a buildup of soil P; and (4) Ritz and Merka (2013) list maximum yearly $\mathrm{BL}$ application rate of $14.6 \mathrm{Mg}$ $\mathrm{ha}^{-1}$ for corn. These typical BL management approaches were used in determining our BL application rate during phase-1.

Plots were established in early spring of 2014 at the University of Georgia Gibbs Farm located in Tift County, Georgia $\left(31^{\circ} 26^{\prime} 08^{\prime \prime} \mathrm{N}, 83^{\circ} 35^{\prime} 20^{\prime \prime} \mathrm{W}\right.$; figure 1). The climate is humid subtropical, summers are hot and humid, and winters are cool with few hard freezes. Average monthly temperatures range from $11^{\circ} \mathrm{C}$ in January to $27^{\circ} \mathrm{C}$ in July and August with a mean annual temperature of $18.7^{\circ} \mathrm{C}$. The 50 -year mean annual rainfall is $1,200 \mathrm{~mm}$, with mean monthly distribution from $70 \mathrm{~mm}$ in May and October to $130 \mathrm{~mm}$ in March, June, and July (Bosch et al. 2020). However, regular periods of below average rainfall occur with negative impact on water availability and agricultural productivity.

The mean daily temperature and cumulative rainfall for 2014 through 2017 are shown in figure 2. Mean daily temperature 


\section{Figure 1}

Layout of replication, plots, grass buffer strips, and runoff collection system. Numbers on the upper end of plot boundaries indicate corresponding treatment numbers (see table 1). Small surface ditches separate plots conveying plot runoff toward collecting systems.

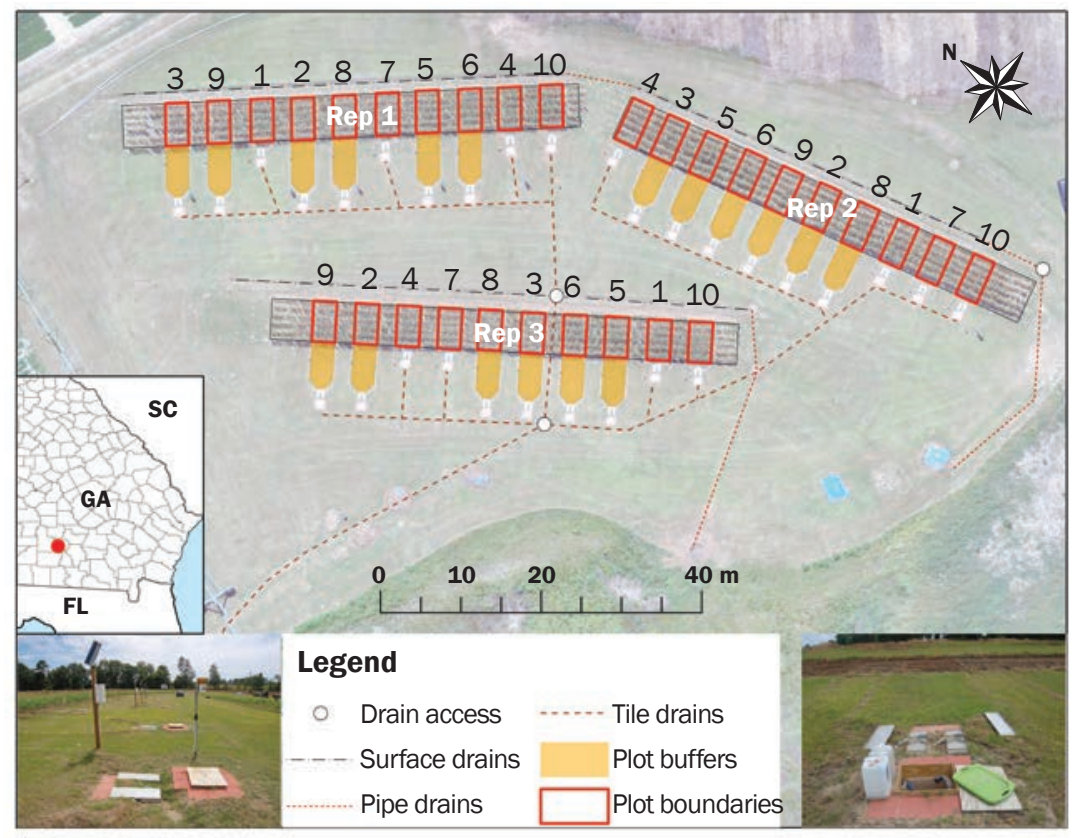

each month steadily rose from below $13^{\circ} \mathrm{C}$ in January to a peak of $24^{\circ} \mathrm{C}$ to $28^{\circ} \mathrm{C}$ in the summer months, then steadily declined to below $15^{\circ} \mathrm{C}$ in December. Cumulative rainfall at the end of each month from the start of the year was similar between 2014 and 2016 and between 2015 and 2017 except in November and December, where it diverged. Total yearly cumulative rainfall in millimeters was 1,478 in $2014,1,300$ in 2016, 1,165 in 2015, and 1,016 in 2017 (figure 2). Whenever a drought risk was thought to occur, $25 \mathrm{~mm}$ of irrigation at a time was applied using a travelling gun to avoid crop loss. This occurred four to six times during a corn season. The runoff amount and quality data for what is reported here came from 29 storms over a 21-month period from May of 2015 through January of 2017. Seventeen occurred in 2015 and 11 in 2016. Storms per month varied from one to six. Mean storm amount was $30 \mathrm{~mm}$ (range 7 to $91 \mathrm{~mm}$ ) and the prerunoff five-day antecedent storm amount that likely influenced runoff generation was $23 \mathrm{~mm}$ (range 0 to $73 \mathrm{~mm}$ ).

The site was previously an established bermudagrass field managed over the past decade with frequent mowing but limited fertilization. The experimental design included nine treatments randomly assigned to plots in each of three replications. Two replications were assigned to the upper and one to the lower landscape positions due to field dimensions (figure 1). Treatments consisted of three nutrient sources (NPK, BL, and $\mathrm{BL}+\mathrm{FGDG}$ ) applied to the cropped areas and three GBS treatments (no GBS [GBS], GBS without FGDG [GBS-FGDG], and GBS with FGDG [GBS+FGDG]) (table

\section{Figure 2}

(a) Mean daily temperature per month and (b) cumulative rainfall from start of a year to end of a month from 2014 through 2017.

(a)

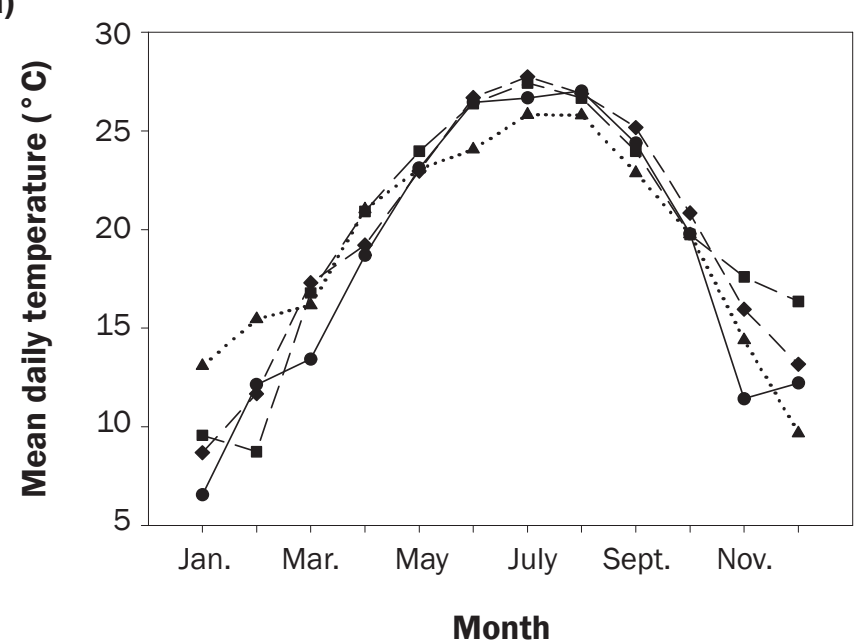

(b)

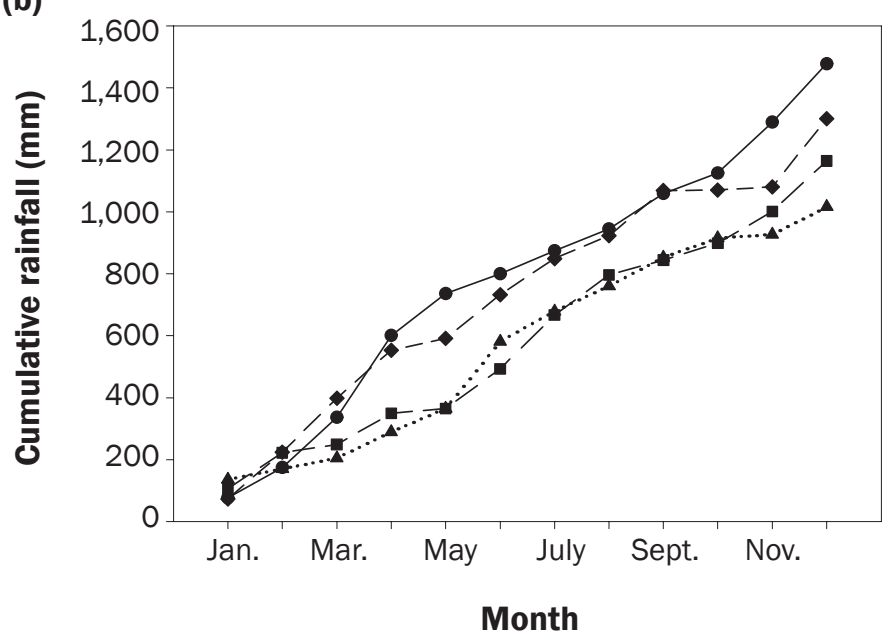


1). The field physiography precluded the inclusion of a fourth nutrient source treatment (NPK+FGDG) with and without GBS. However, in May of 2014, we determined we could add NPK+FGDG without GBS. This gave us an additional treatment to evaluate effectiveness of FGDG applied with NPK in the field. Application methods and rates for BL and FGDG are described below.

Cropped plots were $3.05 \mathrm{~m}$ across slope by $5.49 \mathrm{~m}$ downslope, with a $2.13 \mathrm{~m}$ alley between plots. The GBS area, placed immediately downslope of plots, was $6.1 \mathrm{~m}$ long with the same width as cropped plots and was bounded on three sides by 10 to $15 \mathrm{~cm}$ wide and high berms (see below) created with soil from a nearby field. Mean cropped plot slope was $3.9 \%$ in replication 1 (plot mean $2.8 \%$ to $6.2 \%$ ), $5.5 \%$ in replication 2 (plot mean $3.6 \%$ to $6.3 \%$ ), and $3.7 \%$ in replication 3 (plot mean $2.7 \%$ to $4.5 \%)$. Equivalent values for mean GBS slopes were $5.8 \%(5.5 \%$ to $6.3 \%)$, $7.1 \%(6.4 \%$ to $8.0 \%)$, and $4.2 \%(3.3 \%$ to $4.8 \%$, respectively. Surface ditches, approximately $0.50 \mathrm{~m}$ deep and $0.6 \mathrm{~m}$ wide at the top, were established along the upper end of each replication to divert surface water away from the plots.

Soil Sampling. The dominant soil series in the field is Carnegie sandy loam (fine, kaolinitic, thermic Plinthic Kandiudults) (USDA NRCS 2021). The surface $15 \mathrm{~cm}$ horizon is a brown sandy loam overlaying a dominantly sandy clay argillic subsoil. The series is strongly to very strongly acidic unless modified through liming. Soil cores, approximately $120 \mathrm{~cm}$ deep and $6.4 \mathrm{~cm}$ diameter, were collected with a tractor mounted hydraulic sampler (Giddings Machine Company, Windsor, Colorad0) from cropped and GBS areas prior to corn planting in early April of 2014 to establish baseline soil characteristics. Core holes were backfilled with a 50-50 sand and kaolin mixture. Based on these samples, mean sand and clay content was $80.6 \%$ and $8.7 \%$, respectively, in the 0 to $8 \mathrm{~cm}$ depth (loamy sand) and $74.3 \%$ and $15.4 \%$, respectively, in the 8 to $15 \mathrm{~cm}$ depth (sandy loam). Mean soil $\mathrm{pH}$ varied between 5.2 and 5.4 across plots. Before and after each corn season, additional soil samples were collected by hand from the 0 to $8 \mathrm{~cm}$ and 8 to $15 \mathrm{~cm}$ depths to determine fertilizer requirements and evaluate nutrient stratification.

Soil samples were sent to the Agricultural and Environmental Services Laboratories, University of Georgia (UGA) in Athens,

Table 1

Treatment details by plot fertilization and buffer arrangement and amendment.

\begin{tabular}{|c|c|c|c|c|c|}
\hline \multirow[b]{2}{*}{ Treatment \# } & \multicolumn{2}{|l|}{ Plot* } & \multicolumn{3}{|l|}{ Buffert } \\
\hline & Fertilizer & Gypsum & Buffer & Gypsum & Buffer designation \\
\hline 1 & NPK & None & No buffer & None & $-G B S$ \\
\hline 2 & NPK & None & Buffer & None & GBS-FGDG \\
\hline$\underline{3}$ & NPK & None & Buffer & FGDG & GBS+FGDG \\
\hline 4 & $\mathrm{BL}$ & None & No buffer & None & $-\mathrm{GBS}$ \\
\hline 5 & $\mathrm{BL}$ & None & Buffer & None & GBS-FGDG \\
\hline 6 & $\mathrm{BL}$ & None & Buffer & FGDG & GBS+FGDG \\
\hline 7 & $\mathrm{BL}$ & FGDG & No buffer & None & $-\mathrm{GBS}$ \\
\hline 8 & $\mathrm{BL}$ & FGDG & Buffer & None & GBS-FGDG \\
\hline$\underline{9}$ & $\mathrm{BL}$ & FGDG & Buffer & FGDG & GBS+FGDG \\
\hline 10 & NPK & FGDG & No buffer & None & $-\mathrm{GBS}$ \\
\hline
\end{tabular}

*NPK = inorganic fertilizer with $\mathrm{N}$ equivalent of $224 \mathrm{~kg} \mathrm{ha}^{-1}$ and $\mathrm{P}$ and $\mathrm{K}$ equivalent to that from $\mathrm{BL} . \mathrm{BL}=$ broiler litter at rate of $13.45 \mathrm{Mg} \mathrm{ha}^{-1}$ and $\mathrm{N}$ equivalent of $224 \mathrm{~kg} \mathrm{ha}^{-1}$ assuming $~ 57 \%$ mineralization. FGDG = flue gas desulfurization gypsum at rate of $13.45 \mathrm{Mg} \mathrm{ha}^{-1}$.

†Buffer FGDG at a rate of $13.45 \mathrm{Mg} \mathrm{ha}^{-1}$. GBS = grass buffer strip.

Georgia, for analysis. Mean Mehlich-1 extracted soil $\mathrm{P}$ in the 0 to $15 \mathrm{~cm}$ depth on samples taken on March 21, 2014, was 21.4, 17.7 , and $20.2 \mathrm{mg} \mathrm{kg}^{-1}$ in NPK, BL, and BL+FGDG fertilized plots, respectively.A year later (March 4, 2015), values were 18.9, 43.2, and $55.1 \mathrm{mg} \mathrm{kg}^{-1}$, respectively. Two years later (April 14, 2016), equivalent values were 17.1, 50.7, and $74.1 \mathrm{mg} \mathrm{kg}^{-1}$. By March 17, 2017, levels had increased to $37.8,57.7$, and 70.1 $\mathrm{mg} \mathrm{kg}^{-1}$, respectively. Thus, in the 0 to $15 \mathrm{~cm}$ depth, Mehlich-1 extracted soil $\mathrm{P}$ increased in three years by 2- to 3- and 2- to 4-fold in $\mathrm{BL}$ and $\mathrm{BL}+\mathrm{FGDG}$ fertilized plots compared with those of NPK fertilization, respectively. The higher values in the BL+FGDG fertilized plot suggest possible complexion and retention in soil of $\mathrm{P}$ from $\mathrm{BL}$ with $\mathrm{Ca}$ and possibly $\mathrm{S}$ from gypsum. The UGA recommendations classify soil test $\mathrm{P}$ values generally as low when Mehlich-1 P value $\leq 20 \mathrm{mg} \mathrm{kg}^{-1}$, medium when between 20 and $35 \mathrm{mg} \mathrm{kg}^{-1}$, high when between 35 and $55 \mathrm{mg} \mathrm{kg}^{-1}$, and very high when $>55 \mathrm{mg} \mathrm{kg}^{-1}$.

Agronomic Practices. The Georgia Corn Production Manual (Lee 2012) was used for management decisions, outside of those specific to the 10 treatments, including managing the rye (Secale cereale) Austrian winter pea (Pisum arvense) cover crop mixture planted in October and terminated in April each year. Tillage prior to corn planting consisted of disking to approximately 20 $\mathrm{cm}$ deep with several passes of a $4.6 \mathrm{~m}$ disk harrow (Athens Plow Company Inc., Athens, Tennessee), followed by a four row KMC ripper bedder with attached subsoiler (KMC,
Kelly Manufacturing Co., Tifton, Georgia), and finally a KMC $3.7 \mathrm{~m}$ field conditioner.

In April of 2015 and 2016, the cover crop mixture was rolled and sprayed with glyphosate prior to tillage as above. Similar tillage was performed prior to planting the cover crop mixture in the fall following rolling of corn stover. Corn (Pioneer P1690YHR) was planted in spring (April 24, 2014; May 14, 2015; May 13, 2016) to the full area of each replication at $91.4 \mathrm{~cm}$ spaced rows (six rows per plot), and 18 to $20 \mathrm{~cm}$ between plants in each row. Target planting density was 8,700 plants $\mathrm{ha}^{-1}$. Corn was hand harvested in September (September 4, 2014; September 14, 2015; September 19, 2016). The cover crop mixture was planted on October 28, 2014, October 5, 2015, and October 14, 2016. Weed control was performed once or twice each season using glyphosate applied before corn reached V4 stage and immediately after planting the cover crop mixture.

Small ditches, which served as plot boundaries as well as for conveying plot runoff to collectors (see below), were established prior to applying fertilizer and FGDG by hand in the week following corn planting. The BL was from a local producer near Ashburn, Georgia, who cleans out the broiler houses annually after producing five to six flocks. Each year, the FGDG source was Southern Company's Bowen Plant near Cartersville, Georgia. Once delivered, both BL and FGDG were kept under cover near the research site until applied on the plots-less than three weeks. Table 2 summarizes nutrient content of FGDG and BL used from 2014 to 2016 as determined at UGA after site delivery but 
Table 2

Nutrient content of applied flue gas desulfurization gypsum (FGDG) and broiler litter (BL) for 2014 to 2016.

\begin{tabular}{|c|c|c|c|c|c|c|c|c|}
\hline \multirow[b]{2}{*}{ Nutrient* } & \multicolumn{4}{|c|}{ FGDG $\left(\mathrm{kg} \mathrm{Mg}^{-1}\right)$} & \multicolumn{4}{|c|}{$\mathrm{BL}\left(\mathrm{kg} \mathrm{Mg}^{-1}\right)$} \\
\hline & 2014 & 2015 & 2016 & Average & 2014 & 2015 & 2016 & Average \\
\hline Aluminum (Al) & 0.33 & 0.09 & 0.06 & 0.16 & 0.69 & 1.20 & 2.09 & 1.33 \\
\hline Boron (B) & $N G$ & $N G$ & 0.03 & 0.03 & 0.24 & 0.20 & 0.17 & 0.20 \\
\hline Calcium (Ca) & 236.23 & 216.07 & 256.48 & 236.26 & 19.95 & 18.20 & 19.23 & 19.13 \\
\hline Copper (Cu) & 0.01 & $N G$ & $N G$ & 0.01 & 0.31 & 0.27 & 0.21 & 0.26 \\
\hline Iron (Fe) & 0.49 & 0.31 & 0.22 & 0.34 & 0.49 & 0.93 & 1.10 & 0.84 \\
\hline Lead $(\mathrm{Pb})$ & $N G$ & 0.07 & 0.07 & 0.07 & ND & ND & ND & ND \\
\hline Magnesium (Mg) & 0.14 & 0.05 & 0.12 & 0.10 & 5.87 & 6.50 & 5.04 & 5.80 \\
\hline Phosphorus (P) & 0.05 & $N G$ & 0.02 & 0.04 & 12.46 & 12.74 & 10.14 & 11.78 \\
\hline Potassium (K) & 1.56 & $N G$ & $N G$ & 1.56 & 26.10 & 30.61 & 27.89 & 28.20 \\
\hline Silicon (Si) & 0.51 & 0.60 & 0.36 & 0.49 & ND & ND & ND & ND \\
\hline Sodium (Na) & 0.11 & $N G$ & $N G$ & 0.11 & 8.34 & 7.32 & 7.08 & 7.58 \\
\hline Sulfur (S) & 187.42 & 181.42 & 188.44 & 185.76 & 7.12 & 7.70 & 6.22 & 7.01 \\
\hline Zinc (Zn) & 0.01 & $N G$ & $N G$ & 0.01 & 0.34 & 0.40 & 0.32 & 0.35 \\
\hline Total carbon (DC) & 2.50 & 2.70 & 2.83 & 2.68 & ND & ND & ND & ND \\
\hline Total nitrogen (DC) & 0.90 & 0.30 & 0.20 & 0.47 & 28.70 & 30.14 & 29.30 & 29.38 \\
\hline FGD gypsum purity (\%) & ND & 92.95 & 97.03 & 94.99 & NA & NA & NA & NA \\
\hline FGD gypsum Ca (\%) & 23.62 & 21.63 & 25.65 & 23.63 & NA & NA & NA & NA \\
\hline FGD gypsum S (\%) & 18.74 & 18.17 & 18.84 & 18.58 & NA & NA & NA & NA \\
\hline
\end{tabular}

Notes: Analyses done at the Agricultural and Environmental Services Laboratories of the University of Georgia, Athens, Georgia. Values for each year are averages of three samples analyzed that year. $\mathrm{DC}=$ dry combustion. $\mathrm{NG}=$ negligible amount. ND = not determined. $\mathrm{NA}=$ not applicable.

*All in elemental form.

before plot application. The target $\mathrm{N}$ rate for all treatments was $224 \mathrm{~kg} \mathrm{~N} \mathrm{ha}^{-1}$. The amount of BL applied was estimated based on a $\sim 57 \% \mathrm{~N}$ mineralization rate (Ritz and Merka [2013] and our own experience). Urea (46:0:0) was the primary source of $\mathrm{N}$ for NPK treatments while P, K, and S, based on amounts equivalent to those in the BL, were from mono-ammonium phosphate (MAP; $50 \% \mathrm{P}_{2} \mathrm{O}_{5}$ and $10 \% \mathrm{~N}$ ), muriate of potash (MOP; $60 \% \mathrm{~K}_{2} \mathrm{O}$ ), and a $90 \%$ pure $\mathrm{S}$ product all purchased from a local supplier. As shown in table 2, the average N, P, K, and $\mathrm{S}$ content in kilograms per megagram of the applied BL during 2014 to 2016 was 29.4, $11.8,28.2$, and 7.0, respectively, which translates to application rates of 224, 157,378, and $94 \mathrm{~kg} \mathrm{ha}^{-1}$, respectively, based on the 13.45 $\mathrm{Mg} \mathrm{ha}^{-1}$ litter application rate and $57 \%$ mineralization for $\mathrm{N}$.

Water Sample Collection and Analyses. Ditches, 15 to $20 \mathrm{~cm}$ deep and $\sim 15 \mathrm{~cm}$ wide along the southern end of plots and established prior to corn planting, served as plot boundaries, and directed runoff to the measuring and collecting systems. The flume collection system, a modification of that of Franklin et al. (2001), was designed to direct a fifth of the total runoff volume into collec- tion vessels. Two $15 \mathrm{~L}$ plastic jugs for runoff collection were placed inside a $60 \times 40 \times$ $45 \mathrm{~cm}$ plastic tote placed in a pit containing a plywood box with a cover to protect the vessels from sunlight and rain. Controlled laboratory and field tests of the modified collector system consistently gave very close to $20 \%$ (one-fifth) capture of water released upslope. To eliminate problems from perched water pushing the totes and jugs above runoff collection points (which occurred in 2014), a system of $10 \mathrm{~cm}$ diameter primary tile drains was installed below the collection pits to convey water to a central $15 \mathrm{~cm}$ diameter secondary tile drain. The latter tile drains conveyed water to a natural ditch at the northwest corner of the field (figure 1).

Runoff measurement and sample collection began in May of 2015 after establishment of the field tile drains. Collection jugs were checked within 24 hours, except for weekends, of significant rainfall events. When runoff occurred, the volume in each jug was measured and two $1 \mathrm{~L}$ composite subsamples were saved in acid-washed Nalgene bottles. Samples were taken to the laboratory and kept in coolers $\left(4^{\circ} \mathrm{C}\right)$ pending processing. One of the two samples was partitioned into filtered (0.45 micron filter) and unfiltered fractions, which were kept in coolers or freezers. The second sample was acidified and kept in a freezer as a backup. Subsamples from each of the filtered and unfiltered fractions were transferred into $20 \mathrm{~mL}$ vials and placed on ice (or frozen) for transfer to the Analytical Services Laboratories at the University of Florida (UF) in Gainesville, Florida. There, filtered samples were analyzed for ammonium-nitrogen $\left(\mathrm{NH}_{4}-\mathrm{N}\right)$, nitrate-nitrogen $\left(\mathrm{NO}_{3}-\mathrm{N}\right)$, and dissolved reactive phosporus (DRP), and unfiltered samples were analyzed for total Kjeldahl N (TKN) and total P (TP) using standard US Environmental Protection Agency (USEPA) methods with appropriate quality assurance protocols (UF-IFAS Analytical Services Laboratories 2016).

Data Processing and Analyses. Measured runoff was multiplied by a factor of 5 due to the splitter arrangement on the runoff collector to estimate total runoff from catchment areas (cropped plot or cropped plot and GBS) for each event. Total runoff was used to estimate nutrient load by multiplying the event volume by the event concentration. The runoff volume was normalized by the catchment area and expressed in millimeters, which allowed comparison among treat- 
ments of the percentage rainfall partitioned into runoff.

Although there were 29 storms that led to runoff events in some plots, variability among replications and plots in runoff response per event was large. For an event, there might be no runoff in plots of one replication while the other two replications would have several plots with runoff. Similarly, within a replication, runoff might occur in as few as one or up to all plots. While some runoff was measured for all 29 events, samples for nutrient analysis were not collected for all events because of cost considerations, especially if events occurred within a few days of each other. Typical intervals between two consecutive runoff events varied from 1 to 13 days.

Runoff, concentration, and load data were normalized by converting to natural logs prior to statistical analysis. Concentration values expressed originally as milligrams per liter were multiplied by 1,000 giving micrograms per liter and 1 was added to these values before converting to natural logs. Load in kilograms per hectare were similarly converted to grams per hectare and 1 was added to these values before converting to natural logs. These steps were applied to ensure values were greater than one prior to conversion. Concentration and load data were back transformed for presentation in tables and figures using appropriate conversion factors.

Because more data were collected for runoff events than for nutrient analyses, statistical analyses for runoff, nutrient concentration, and load were conducted separately. For statistical analyses, values were set to missing and not included to avoid negatively biasing results where runoff volume or nutrient concentration (or load) were zero or missing. In other words, we avoided the use of zero values in the data sets.

The statistical analyses were conducted using SAS Enterprise Guide version 7.15 (SAS Institute Inc. 2017) and the SAS/STAT 15.1 (SAS Institute Inc. 2016) MIXED procedure to determine treatment effects on runoff, nutrient concentration, and load. Treatments were assigned values from 1 to 10 (table 1) to simplify the analyses and were considered fixed effects. A set of a priori determined contrasts were used to evaluate specific treatment contrasts using LSMESTIMATE statement. Several additional factors were included in the model as covariate effects to account for plot differ- ences, time since fertilizer application, and antecedent soil moisture conditions. These included plot percentage slope (PSLP), days after planting (DAP) to runoff event, rainfall plus irrigation amount during the five days prior to a runoff event (RN_5D), and rainfall plus irrigation amount during the previous 24 hours (RN_1D) prior to a runoff event. Covariates were included in the model as continuous fixed effects. A REPEATED statement was used to account for any autocorrelation among runoff events within a year using an autoregressive first order covariance structure, $\operatorname{AR}(1)$. Random effects in the model were replication, year, and event, where event represents rainfall events identified sequentially within each year. Significant treatment effects were identified at the $p<$ 0.05 level for percentage runoff, concentrations of $\mathrm{NO}_{3}-\mathrm{N}$, DRP, and TP, and loads of $\mathrm{NH}_{4}-\mathrm{N}, \mathrm{NO}_{3}-\mathrm{N}, \mathrm{DRP}$, and TP using $\log$ normal-transformed data. Percentage differences between paired treatments were calculated based on back transformed least square means.

To assess effect of fertilizer source on runoff and nutrient concentration and load, our contrasts compared BL versus NPK, $\mathrm{BL}+\mathrm{FGD}$ versus $\mathrm{NPK}$, and $\mathrm{BL}+\mathrm{FGD}$ versus BL. For GBS effect, we compared GBS-FGDG versus -GBS, GBS+FGDG versus -GBS, and GBS+FGDG versus GBSFGDG. The NPK and -GBS combination versus that of NPK+FGDG and -GBS comparison indicates the influence of adding FGDG to inorganically fertilized plots in the absence of GBS.

\section{Results and Discussion}

Runoff. Twenty-nine storm events from May of 2015 through January of 2017 produced runoff. Irrigation had been applied immediately prior to only two of these events. If all plots had produced runoff for each event we would expect $(29 \times 3) 87$ observations per treatment. Because this was not the case, there were 35 to 52 observations per treatment identified as being appropriate for use in the statistical analyses. The mean rainfall amount that led to runoff was $30 \mathrm{~mm}$ (range 7 to $92 \mathrm{~mm}$ ) while the mean prerunoff fiveday antecedent rainfall and irrigation was $23 \mathrm{~mm}$ (range 0 to $73 \mathrm{~mm}$ ). Figure 3 shows variability within and across treatments for

\section{Figure 3}

Box plots showing variability of percentage runoff by treatment based on the original nontransformed data. Boxes enclose data within the $25^{\text {th }}$ and $75^{\text {th }}$ percentiles. Dotted and sold lines within boxes represent means and medians, respectively. Whiskers represent data at 90 th percentile. Treatment details: $1=$ NPK and (-GBS); $2=$ NPK and (GBS-FGDG); $3=$ NPK and (GBS+F$\mathrm{GDG}) ; 4=\mathrm{BL}$ and $(-\mathrm{GBS}) ; 5=\mathrm{BL}$ and (GBS-FGDG); $6=\mathrm{BL}$ and $(\mathrm{GBS}+\mathrm{FGDG}) ; 7=(\mathrm{BL}+\mathrm{FGDG})$ and $(-\mathrm{GBS}) ; 8=(\mathrm{BL}+\mathrm{FGDG})$ and $(\mathrm{GBS}-\mathrm{FGDG}) ; 9=(\mathrm{BL}+\mathrm{FGDG})$ and $(\mathrm{GBS}+\mathrm{FGDG}) ; 10=(\mathrm{NPK}+\mathrm{FGDG})$ and $(-\mathrm{GBS}) . \mathrm{NPK}=$ inorganic fertilizer; $\mathrm{BL}=$ broiler litter; $\mathrm{FGDG}=$ flue gas desulfurization gypsum. $Y$-axis is truncated. Values not shown are 60.5 and 72.5 for treatment 1 and 59.8 for treatment 9 .

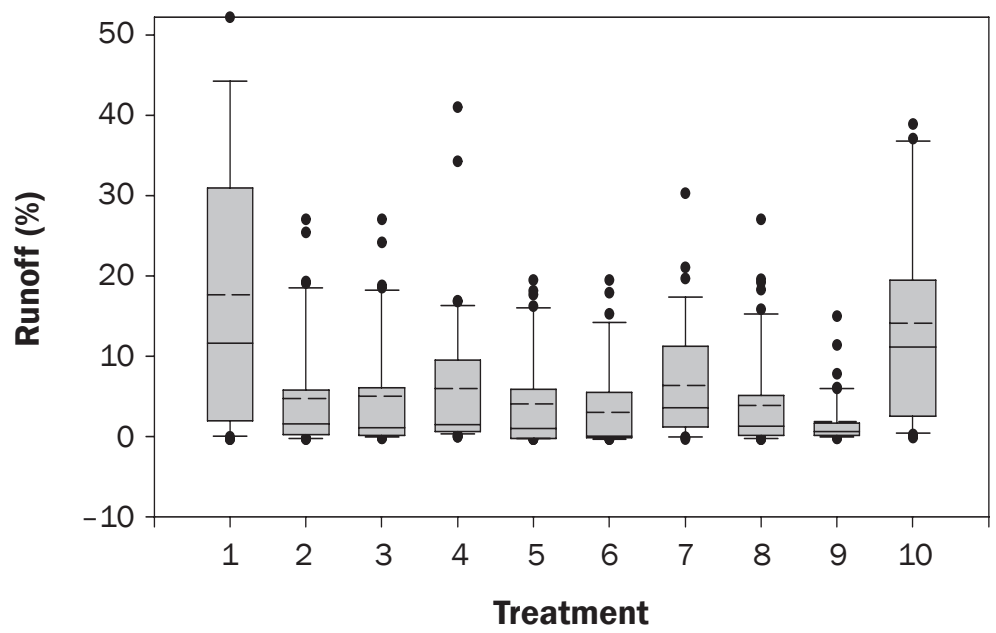


percentage runoff using the original untransformed data. The box plots of treatments 2 through 9 show lower percentage runoff and variability than treatments 1 (NPK and $-\mathrm{GBS})$ and 10 (NPK+FGDG and -GBS), indicative of the effects of BL, BL+FGDG, and GBS with or without FGDG amendment in reducing runoff. A GBS effect is indicated by the general downward trend of box depth (25th to 75 th percentile) within each fertilizer treatment group $(1,2$, and 3 ; 4,5 , and 6;7,8, and 9) and lower mean and median values. This is particularly evident for treatments 7 to 9 (BL+FGDG fertilization). Treatment 9, where BL was applied to the field and both the field and GBS received FGDG, had the least observed percentage runoff with the least variability.
Results from analysis of variance regarding runoff are shown in table 3 . Treatment, plot slope, the prerunoff five-day antecedent rainfall + irrigation, and the interval between planting and runoff dates had significant effects on percentage runoff. Table 4 shows back-transformed least square means (LS-means) and significance of difference between LS-means of paired treatments based on analysis of LN-transformed data. Under NPK fertilization (treatment 1, 2, and 3), percentage runoff was reduced by $\sim 67 \%$ for GBS-FGDG and GBS+FGDG compared with - GBS. Percentage runoff was not different between GBS-FGDG and GBS+FGDG. Under BL fertilization (treatment 4, 5, and 6), percentage runoff for GBS+FGDG decreased by $52 \%$ compared with -GBS and by $46 \%$ compared with GBS-FGDG. Percentage runoff was not different between GBS-FGDG and-GBS. Under BL+FGDG fertilization (treatment 7, 8, and 9), GBS had no significant effect on percentage runoff. Comparison among -GBS plots (treatments 1,4 , and 7) showed a $\sim 56 \%$ reduction in percentage runoff for $\mathrm{BL}$ and BL+FGDG compared with NPK fertilization. There was no difference between BL+FGDG versus BL or between NPK+FGDG versus NPK fertilization. Comparison within GBS-FGDG or GBS+FGDG plots showed no fertilization source effect on percentage runoff. Percentage runoff was $72 \%$ less from treatment 9 , the combined BL+FGDG and GBS+FGDG treatment, compared with treatment 1, NPK and-GBS, considered one

\section{Table 3}

Analysis of variance evaluating treatment, plot slope, the one-day rainfall + irrigation causing runoff, the prerunoff five-day antecedent rainfall + irrigation, and the number of days between corn planting and runoff event on nutrient concentration and load and rainfall + irrigation partitioned into runoff.

\begin{tabular}{|c|c|c|c|c|c|c|c|c|}
\hline \multirow[b]{2}{*}{ Variable } & \multirow[b]{2}{*}{ Statistics } & \multicolumn{7}{|l|}{ Effect } \\
\hline & & TRT & PSLP & RN_1D & RN_1D × RN_1D & RN_5d & RN_5d $\times$ RN_5d & DAP \\
\hline \multirow[t]{2}{*}{ Runoff (\%)* } & FValue & 5.77 & 7.25 & 1.9 & 1.26 & 17.17 & 24.95 & 20.32 \\
\hline & ProbF & 0.0008 & 0.0132 & 0.1747 & 0.2676 & 0.0001 & $<0.0001$ & $<0.0001$ \\
\hline \multicolumn{9}{|c|}{ Concentration $\left(\mu \mathrm{g} \mathrm{L}^{-1}\right)$} \\
\hline \multirow[t]{2}{*}{$\mathrm{NH}_{4}-\mathrm{N}$} & FValue & 1.75 & 2.11 & 0.07 & 0.18 & 0.08 & 1.16 & 4.39 \\
\hline & ProbF & 0.1545 & 0.1636 & 0.7935 & 0.6699 & 0.7768 & 0.2872 & 0.0423 \\
\hline \multirow[t]{2}{*}{$\mathrm{NO}_{3}-\mathrm{N}$} & FValue & 2.58 & 0.03 & 5.3 & 5.53 & 0.2 & 0.36 & 11.41 \\
\hline & ProbF & 0.0471 & 0.8713 & 0.0258 & 0.0231 & 0.657 & 0.5491 & 0.0016 \\
\hline \multirow[t]{2}{*}{ TKN } & FValue & 1.93 & 0.54 & 1.09 & 1.86 & 1.24 & 2.39 & 1.85 \\
\hline & ProbF & 0.1178 & 0.4731 & 0.3025 & 0.1799 & 0.271 & 0.1301 & 0.1813 \\
\hline \multirow[t]{2}{*}{ DRP } & FValue & 5.07 & 2.4 & 2.35 & 1.11 & 0.47 & 1.03 & 12.52 \\
\hline & ProbF & 0.0015 & 0.1347 & 0.1325 & 0.298 & 0.497 & 0.3154 & 0.001 \\
\hline \multirow[t]{2}{*}{ TP } & FValue & 4.68 & 2.58 & 1.75 & 1.32 & 0.25 & 1.21 & 11.07 \\
\hline & ProbF & 0.0024 & 0.1221 & 0.1934 & 0.2581 & 0.6197 & 0.2777 & 0.0019 \\
\hline \multicolumn{9}{|c|}{ Load (g ha ${ }^{-1}$ ) } \\
\hline \multirow[t]{2}{*}{$\mathrm{NH}_{4}-\mathrm{N}$} & FValue & 4.32 & 0.02 & 2.61 & 1.72 & 7.48 & 5.93 & 1.99 \\
\hline & ProbF & $<0.0001$ & 0.8979 & 0.113 & 0.1964 & 0.0091 & 0.0194 & 0.1658 \\
\hline \multirow[t]{2}{*}{$\mathrm{NO}_{3}-\mathrm{N}$} & FValue & 5.05 & 5.59 & 0.13 & 0.61 & 12.01 & 19.28 & 0.02 \\
\hline & ProbF & 0.0021 & 0.0297 & 0.7208 & 0.4372 & 0.0012 & $<0.0001$ & 0.8858 \\
\hline \multirow[t]{2}{*}{ TKN } & FValue & 2.48 & 4.4 & 3.95 & 2.75 & 11.66 & 14.38 & 17.02 \\
\hline & ProbF & 0.0562 & 0.0516 & 0.0525 & 0.1041 & 0.0014 & 0.0005 & 0.0002 \\
\hline \multirow[t]{2}{*}{ DRP } & FValue & 3.09 & 3.71 & 2.59 & 0.45 & 16.51 & 19.82 & 6.38 \\
\hline & ProbF & 0.0025 & 0.0581 & 0.1144 & 0.5062 & 0.0002 & $<0.0001$ & 0.0154 \\
\hline \multirow[t]{2}{*}{ TP } & FValue & 3.3 & 4.35 & 2.08 & 0.68 & 15.52 & 17.51 & 6.86 \\
\hline & ProbF & 0.018 & 0.0531 & 0.1559 & 0.415 & 0.0003 & 0.0001 & 0.0123 \\
\hline
\end{tabular}

Notes: Bolded numbers imply effect is statistically significant. $\mathrm{NH}_{4}-\mathrm{N}=$ ammonium-nitrogen. $\mathrm{NO}_{3}-\mathrm{N}=$ nitrate- $\mathrm{N}$. TKN $=$ total Kjeldhal $\mathrm{N}$. DRP $=$ dissolved reactive phosphorus. TP = total P. TRT $=$ treatment. PSLP $=$ plot slope $(\%)$. RN_1D = one day rainfall + irrigation that led to runoff $(\mathrm{mm})$. RN_5D = prerunoff five-day antecedent rainfall + irrigation $(\mathrm{mm})$. DAP = days after planting up to runoff event.

*Percentage runoff $=$ percentage of rainfall + irrigation that is partitioned into runoff. 
Table 4

Back-transformed least square means (LS-means), significance of difference between LS-means of paired treatments based on analysis of LN-transformed data (SoD), and ([LS-means - standard error] to [LS-means + standard error]) for nutrient concentration and load for ammonium $\mathrm{N}$ $\left(\mathrm{NH}_{4}-\mathrm{N}\right)$, nitrate- $\mathrm{N}\left(\mathrm{NO}_{3}-\mathrm{N}\right)$, total Kjeldahl $\mathrm{N}(\mathrm{TKN})$, dissolved reactive phosphorus (DRP), and total phosphorus (TP).

\begin{tabular}{|c|c|c|c|c|c|c|c|c|c|c|c|}
\hline \multirow[b]{2}{*}{ Variable } & \multirow[b]{2}{*}{ Statistics } & \multicolumn{10}{|l|}{ Treatment } \\
\hline & & 1 & 2 & 3 & 4 & 5 & 6 & 7 & 8 & 9 & 10 \\
\hline \multirow{4}{*}{$\begin{array}{l}\text { Runoff } \\
(\%)^{*}\end{array}$} & LS-means & 10.3 & 3.7 & 3.2 & 4.3 & 3.8 & 2.1 & 4.8 & 3.4 & 2.9 & 7.6 \\
\hline & SoD & $\mathrm{a}$ & $\mathrm{cd}$ & $\mathrm{cd}$ & $\mathrm{bc}$ & c & $d$ & $\mathrm{bc}$ & $\mathrm{cd}$ & $\mathrm{cd}$ & $a b$ \\
\hline & LS-means $\mp$ SE & (8.5 to & (3.0 to & (2.6 to & (3.5 to & (3.1 to & (1.7 to & (3.9 to & (2.8 to & (2.4 to & (6.1 to \\
\hline & & 12.6) & 4.5) & 3.9) & 5.3) & 4.8) & 2.6) & 5.9) & $4.2)$ & 3.6) & 9.4) \\
\hline \multicolumn{12}{|c|}{ Concentration ( $\mu \mathrm{g} \mathrm{L}^{-1}$ ) } \\
\hline \multirow[t]{3}{*}{$\mathrm{NH}_{4}-\mathrm{N}$} & LS-means & 464 & 425 & 766 & 821 & 507 & 1,324 & 1,062 & 405 & 238 & 715 \\
\hline & SoD & $a b c$ & $a b c$ & $a b c$ & $a b$ & $a b c$ & a & $a b$ & $\mathrm{bc}$ & c & $a b c$ \\
\hline & LS-means $\mp$ SE & $\begin{array}{l}\text { (297 to } \\
725)\end{array}$ & $\begin{array}{l}(272 \text { to } \\
664)\end{array}$ & $\begin{array}{l}485 \text { to } \\
1,210)\end{array}$ & $\begin{array}{l}(522 \text { to } \\
1,292)\end{array}$ & $\begin{array}{l}\text { (311 to } \\
826)\end{array}$ & $\begin{array}{l}\text { (831 to } \\
2,110)\end{array}$ & $\begin{array}{l}(671 \text { to } \\
1,680)\end{array}$ & $\begin{array}{l}\text { (261 to } \\
629)\end{array}$ & $\begin{array}{l}\text { (152 to } \\
374)\end{array}$ & $\begin{array}{l}\text { (442 to } \\
156)\end{array}$ \\
\hline \multirow{3}{*}{$\mathrm{NO}_{3}-\mathrm{N}$} & LS-means & 171 & 152 & 105 & 315 & 147 & 97 & 177 & 134 & 94 & 208 \\
\hline & SoD & $a b c$ & $\mathrm{bc}$ & c & a & $\mathrm{bc}$ & c & $a b c$ & $\mathrm{bc}$ & c & $a b$ \\
\hline & LS-means $\mp$ SE & $\begin{array}{l}\text { (133 to } \\
220)\end{array}$ & $\begin{array}{l}\text { (118 to } \\
195)\end{array}$ & $\begin{array}{l}\text { (81 to } \\
135)\end{array}$ & $\begin{array}{l}\text { ( } 243 \text { to } \\
408)\end{array}$ & $\begin{array}{l}\text { (112 to } \\
193)\end{array}$ & $\begin{array}{l}\text { (74 to } \\
127)\end{array}$ & $\begin{array}{l}\text { (136 to } \\
230)\end{array}$ & $\begin{array}{l}\text { (105 to } \\
171)\end{array}$ & $\begin{array}{l}\text { (73 to } \\
120)\end{array}$ & $\begin{array}{l}(159 \text { to } \\
22)\end{array}$ \\
\hline \multirow[t]{3}{*}{ TKN } & LS-means & 2,037 & 2,552 & 2,663 & 3,701 & 3,376 & 6,166 & 3,699 & 2,633 & 1,350 & 2,464 \\
\hline & SoD & $\mathrm{bc}$ & $a b c$ & $a b c$ & $a b$ & $a b$ & a & $a b$ & $a b c$ & c & $a b c$ \\
\hline & LS-means $\mp$ SE & $\begin{array}{l}(1,455 \text { to } \\
2,850)\end{array}$ & $\begin{array}{l}(1,826 \text { to } \\
3,568)\end{array}$ & $\begin{array}{l}(1,889 \text { to } \\
3,753)\end{array}$ & $\begin{array}{l}(2,631 \text { to } \\
5,205)\end{array}$ & $\begin{array}{l}(2,338 \text { to } \\
4,874)\end{array}$ & $\begin{array}{l}(4,335 \text { to } \\
8,771)\end{array}$ & $\begin{array}{l}(2,617 \text { to } \\
5,227)\end{array}$ & $\begin{array}{l}(1,894 \text { to } \\
3,659)\end{array}$ & $\begin{array}{l}\text { (963 to } \\
1,891)\end{array}$ & $\begin{array}{l}(1,714 \text { to } \\
3,543)\end{array}$ \\
\hline \multirow[t]{3}{*}{ DRP } & LS-means & 433 & 550 & 742 & 1,147 & 819 & 1,367 & 1,086 & 615 & 251 & 367 \\
\hline & SoD & de & $\mathrm{cd}$ & abcd & $a b$ & abcd & a & $a b c$ & bcd & e & de \\
\hline & LS-means $\mp$ SE & $\begin{array}{l}\text { (338 to } \\
554)\end{array}$ & $\begin{array}{l}\text { (429 to } \\
704)\end{array}$ & $\begin{array}{l}\text { (576 to } \\
955)\end{array}$ & $\begin{array}{l}\text { (889 to } \\
1,478)\end{array}$ & $\begin{array}{l}\text { (627 to } \\
1,071)\end{array}$ & $\begin{array}{l}(1,052 \text { to } \\
1,778)\end{array}$ & $\begin{array}{l}\text { (839 to } \\
1,405)\end{array}$ & $\begin{array}{l}\text { (482 to } \\
784)\end{array}$ & $\begin{array}{l}\text { (196 to } \\
322)\end{array}$ & $\begin{array}{l}\text { ( } 282 \text { to } \\
478)\end{array}$ \\
\hline \multirow[t]{4}{*}{ TP } & LS-means & 695 & 847 & 1,095 & 1,808 & 1,214 & 2,187 & 1,491 & 926 & 362 & 646 \\
\hline & SoD & de & $\mathrm{cd}$ & abcd & $a b$ & abcd & a & $a b c$ & bcd & e & de \\
\hline & LS-means $\mp$ SE & (540 to & (659 to & (848 to & $(1,399$ to & (926 to & $(1,675$ to & $(1,148$ to & (724 to & (282 to & (495 to \\
\hline & & 894) & $1,088)$ & $1,414)$ & $2,338)$ & $1,591)$ & $2,855)$ & $1,934)$ & $1,185)$ & 465) & 844) \\
\hline \multicolumn{12}{|c|}{ Load (g ha ${ }^{-1}$ ) } \\
\hline \multirow[t]{3}{*}{$\mathrm{NH}_{4}-\mathrm{N}$} & LS-means & 7.2 & 4.3 & 5.8 & 5.3 & 5.1 & 5.2 & 6.9 & 4.3 & 2.8 & 8.1 \\
\hline & SoD & a & $\mathrm{b}$ & $a b$ & $a b$ & $a b$ & $a b$ & a & $\mathrm{b}$ & c & a \\
\hline & LS-means $\mp$ SE & $\begin{array}{l}(5.7 \text { to } \\
90)\end{array}$ & $\begin{array}{l}(3.4 \text { to } \\
5.4)\end{array}$ & $\begin{array}{l}(4.6 \text { to } \\
7.2)\end{array}$ & $\begin{array}{l}(4.3 \text { to } \\
6.7)\end{array}$ & $\begin{array}{l}(4.0 \text { to } \\
6.5)\end{array}$ & $\begin{array}{l}(4.1 \text { to } \\
6.6)\end{array}$ & $\begin{array}{l}\text { (5.5 to } \\
8.7)\end{array}$ & $\begin{array}{l}\text { (3.5 to } \\
5.4)\end{array}$ & $\begin{array}{l}\text { ( } 2.2 \text { to } \\
3.5)\end{array}$ & $\begin{array}{l}\text { (6.4 to } \\
10.3)\end{array}$ \\
\hline \multirow[t]{3}{*}{$\mathrm{NO}_{3}-\mathrm{N}$} & LS-means & 4.1 & 2.5 & 1.9 & 3.2 & 2.4 & 1.4 & 2.4 & 2.2 & 1.9 & 3.6 \\
\hline & SoD & a & bcd & de & $a b c$ & bcd & e & bcd & $\mathrm{cd}$ & de & $a b$ \\
\hline & LS-means $\mp$ SE & $\begin{array}{l}\text { (3.5 to } \\
4.7)\end{array}$ & $\begin{array}{l}\text { ( } 2.1 \text { to } \\
2.9)\end{array}$ & $\begin{array}{l}(1.6 \text { to } \\
2.2)\end{array}$ & $\begin{array}{l}(2.8 \text { to } \\
3.8)\end{array}$ & $\begin{array}{l}(2.0 \text { to } \\
2.9)\end{array}$ & $\begin{array}{l}(1.2 \text { to } \\
1.7)\end{array}$ & $\begin{array}{l}(2.1 \text { to } \\
2.8)\end{array}$ & $\begin{array}{l}(1.9 \text { to } \\
2.6)\end{array}$ & $\begin{array}{l}(1.6 \text { to } \\
2.2)\end{array}$ & $\begin{array}{l}\text { (3.1 to } \\
4.3 \text { ) }\end{array}$ \\
\hline \multirow[t]{3}{*}{ TKN } & LS-means & 24.8 & 16.9 & 14.8 & 16.5 & 21.0 & 13.3 & 18.4 & 15.6 & 7.8 & 20.2 \\
\hline & SoD & $a$ & a & $a b$ & a & a & $a b$ & a & a & b & a \\
\hline & LS-means $\mp$ SE & $\begin{array}{l}\text { (18.8 to } \\
32.7)\end{array}$ & $\begin{array}{l}\text { (12.8 to } \\
22.3)\end{array}$ & $\begin{array}{l}\text { (11.2 to } \\
19.6)\end{array}$ & $\begin{array}{l}(12.4 \text { to } \\
21.8)\end{array}$ & $\begin{array}{l}\text { (15.6 to } \\
28.2)\end{array}$ & $\begin{array}{l}\text { (9.9 to } \\
17.8)\end{array}$ & $\begin{array}{l}\text { (13.8 to } \\
24.5)\end{array}$ & $\begin{array}{l}\text { (11.9 to } \\
20.5)\end{array}$ & $\begin{array}{l}\text { (5.9 to } \\
10.3)\end{array}$ & $\begin{array}{l}(15.2 \text { to } \\
27.0)\end{array}$ \\
\hline \multirow[t]{3}{*}{ DRP } & LS-means & 6.8 & 5.1 & 5.5 & 6.9 & 6.3 & 4.7 & 7.0 & 5.1 & 3.0 & 4.7 \\
\hline & SoD & $a$ & a & a & a & a & $a b$ & a & a & b & $a b$ \\
\hline & LS-means $\mp$ SE & $\begin{array}{l}(5.7 \text { to } \\
8.0)\end{array}$ & $\begin{array}{l}(4.3 \text { to } \\
6.0)\end{array}$ & $\begin{array}{l}(4.6 \text { to } \\
6.5)\end{array}$ & $\begin{array}{l}\text { (5.8 to } \\
8.3)\end{array}$ & $\begin{array}{l}(5.2 \text { to } \\
7.6)\end{array}$ & $\begin{array}{l}\text { (3.9 to } \\
5.7)\end{array}$ & $\begin{array}{l}\text { (5.9 to } \\
8.4)\end{array}$ & $\begin{array}{l}(4.3 \text { to } \\
6.0)\end{array}$ & $\begin{array}{l}\text { ( } 2.6 \text { to } \\
3.6)\end{array}$ & $\begin{array}{l}\text { (3.9 to } \\
5.7)\end{array}$ \\
\hline \multirow[t]{3}{*}{ TP } & LS-means & 9.7 & 7.1 & 7.0 & 9.6 & 8.8 & 6.2 & 8.9 & 6.8 & 3.6 & 7.1 \\
\hline & SoD & $a$ & a & a & a & a & a & a & a & $b$ & a \\
\hline & LS-means $\mp$ SE & $\begin{array}{l}\text { (8.0 to } 1 \\
1.8)\end{array}$ & $\begin{array}{l}\text { (5.8 to } \\
8.6)\end{array}$ & $\begin{array}{l}\text { (5.8 to } \\
8.5)\end{array}$ & $\begin{array}{l}\text { (7.9 to } \\
11.7 \text { ) }\end{array}$ & $\begin{array}{l}\text { ( } 7.2 \text { to } \\
10.9)\end{array}$ & $\begin{array}{l}(5.0 \text { to } \\
7.6)\end{array}$ & $\begin{array}{l}\text { (7.3 to } \\
10.9)\end{array}$ & $\begin{array}{l}\text { (5.6 to } \\
8.1)\end{array}$ & $\begin{array}{l}2.9 \text { to } \\
4.3)\end{array}$ & $\begin{array}{l}(5.7 \text { to } \\
8.7)\end{array}$ \\
\hline
\end{tabular}

Notes: $\mathrm{SE}=$ standard error. LS-means of paired treatments with the same letter for each nutrient are not significantly different at alpha $=0.05$.

*Percentage runoff $=$ percentage of rainfall + irrigation that is partitioned into runoff. 


\section{Figure 4}

Box plots showing variability of nutrient concentration for (a) dissolved reactive phosphorus (DRP), (b) total phosphorus (TP), (c) nitrate-nitrogen $\left(\mathrm{NO}_{3}-\mathrm{N}\right)$, (d) ammonium-nitrogen $\left(\mathrm{NH}_{4}-\mathrm{N}\right)$, and (e) total Kjeldahl nitrogen (TKN) by treatment based on the original nontransformed data. Boxes enclose data within the 25th and75th percentiles. Dotted and sold lines within boxes represent means and medians, respectively. Whiskers represent data at 9oth percentile. Treatment details: $1=N P K$ and $(-G B S) ; 2=N P K$ and (GBS-FGDG); $3=N P K$ and $(G B S+F G D G) ; 4=B L$ and $(-G B S) ; 5$ $=\mathrm{BL}$ and $(\mathrm{GBS}-\mathrm{FGDG}) ; 6=\mathrm{BL}$ and $(\mathrm{GBS}+\mathrm{FGDG}) ; 7=(\mathrm{BL}+\mathrm{FGDG})$ and $(-\mathrm{GBS}) ; 8=(\mathrm{BL}+\mathrm{FGDG})$ and $(\mathrm{GBS}-\mathrm{FGDG}) ; 9=(\mathrm{BL}+\mathrm{FGDG})$ and $(\mathrm{GBS}+\mathrm{FGDG}) ; 10$ $=(\mathrm{NPK}+\mathrm{FGDG})$ and $(-\mathrm{GBS}) . \mathrm{NPK}=$ inorganic fertilizer; $\mathrm{BL}=$ broiler litter; FGDG = flue gas desulfurization gypsum. $Y$-axis is truncated. Values not shown in (a) are 10,840 to 33,814 for treatments 2 to 7 ; in (b), 17,800 to 50,417 for treatments 3 to 8 ; in (c), 4,372 to 6,625 for treatments 1 to 3 ; in (d), 47,773 to 104,851 for treatments 2 to 7 ; and in (e), 51,047 for treatment 1.

(a)

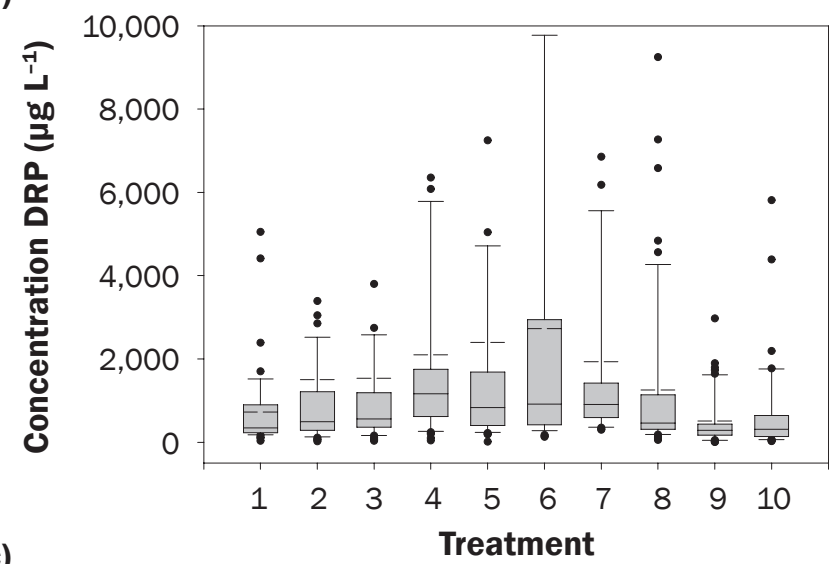

(c)

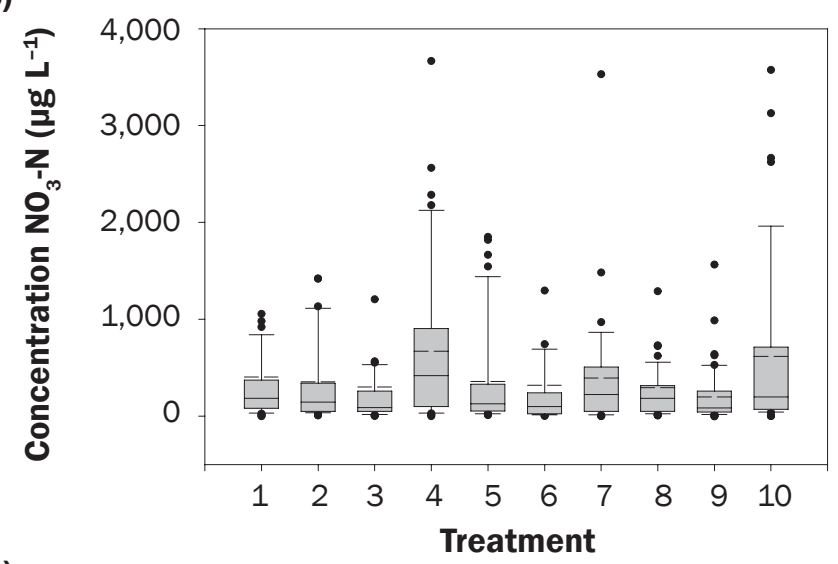

(b)

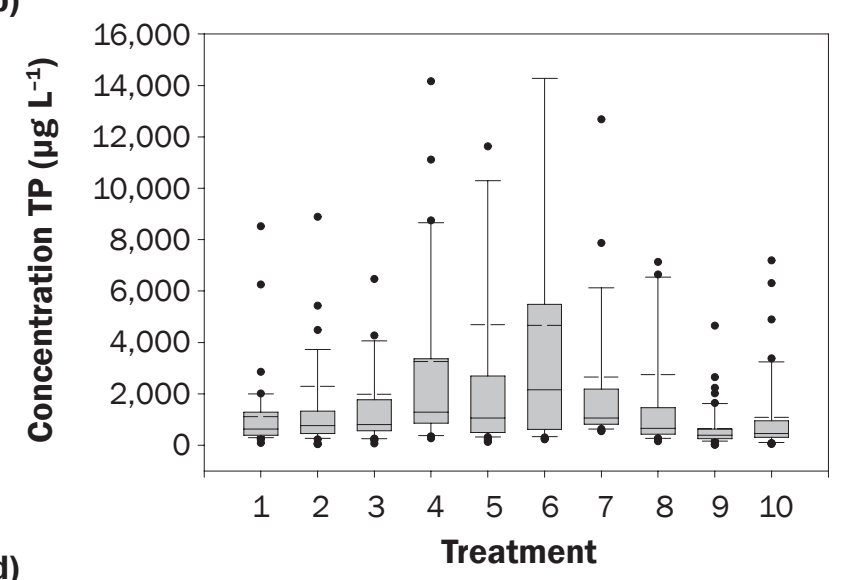

(d)

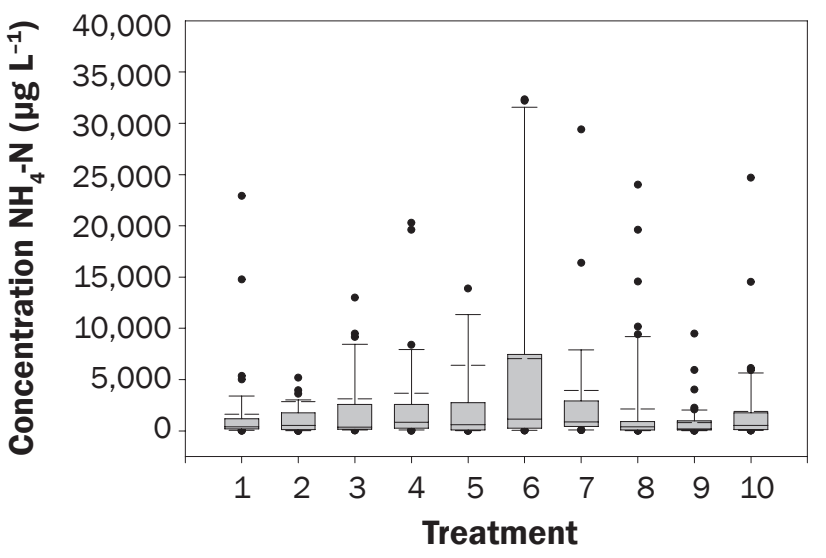

(e)

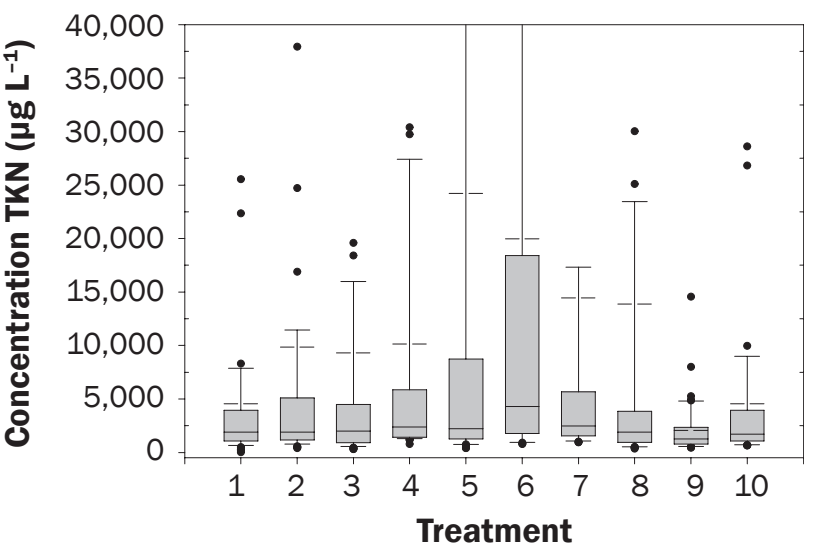

of two standard practices, the other being treatment 4, BL-GBS.
Nutrient Concentration. Figure 4 shows variability within and across treatments for nutrient concentration using the original untransformed data. The box plots generally show a slightly greater range in treatments 4,5 , and $6(\mathrm{BL})$ compared with treatments 
1, 2, and 3 (NPK). The GBS effect appears evident for DRP, TP, and TKN under BL+FGDG (treatment 7, 8, and 9), and for $\mathrm{NO}_{3}-\mathrm{N}$ under $\mathrm{BL}$ and BL+FGDG. Overall, the box plots for treatment 9 (BL+FGDG and GBS+FGDG) show that additions of FGDG to both the cropped and GBS areas consistently led to lower nutrient concentrations with the least variance.

Considering extreme values, those within the 4th quartile (represented by dots in figure 4), BL fertilization (treatment 4, 5, and 6) had a greater number for all nutrients (except for $\mathrm{NO}_{3}-\mathrm{N}$ ) than NPK or BL+FGDG fertilization (Note the $y$-axis in figure 4 is truncated-not all 4 th quartile data are shown). Across all treatments, mean concentration in the 4th quartile compared with the 2 nd and 3 rd quartile combined was 14-fold greater for $\mathrm{NH}_{4}-\mathrm{N}$ and TKN, and 5to 8 -fold greater for the remaining nutrients (for untransformed data). This is in line with what is generally reported in the literature, such as Langdale et al. (1992) and Endale et al. (2014a), that a few extreme storm events contribute the larger portion of nutrient losses in a season.

Table 3 shows results from analysis of variance for nutrient concentration while table 4 shows back-transformed LS-means and significance of difference between LS-means of paired treatments based on analysis of LN-transformed data. None of the variables shown in table 3 had effect on TKN concentration while only the interval between planting and runoff dates had significant effects on concentration of $\mathrm{NH}_{4}-\mathrm{N}$. On the other hand, treatments and the interval between planting and runoff dates had significant effects on concentration of $\mathrm{NO}_{3}-\mathrm{N}$, DRP, and TP. Concentration of $\mathrm{NO}_{3}-\mathrm{N}^{3}$ was also significantly affected by the one-day rainfall + irrigation causing runoff.

Nutrient Concentration under Different Fertilization Treatments. Under NPK fertilization (treatments 1, 2, and 3), GBS had no significant effect on the concentration of any nutrient (table 4). Under BL fertilization (treatments 4, 5, and 6), the only GBS effect observed was the reduction in $\mathrm{NO}_{3}-\mathrm{N}$ concentration by $53 \%$ and $69 \%$ for GBS-FGDG and GBD+FGDG, respectively, compared with -GBS. Under BL+FGDG fertilization (treatments 7, 8, and 9), GBS-FGDG had no effect on concentration of any nutrient compared with -GBS. However, GBS+FGDG decreased concentrations of $\mathrm{NH}_{4}-\mathrm{N}, \mathrm{TKN}$,
DRP, and TP by $65 \%$ to $80 \%$ compared with -GBS. Concentrations of DRP and TP decreased by $\sim 60 \%$ each for GBS+FGDG compared with GBS-FGDG.

Nutrient Concentration under Different Grass Buffer Strips Treatments. In -GBS plots, concentration of DRP and TP increased by $160 \%$ to $165 \%$ for BL compared with NPK, and concentration of DRP and TP increased by $150 \%$ and $115 \%$, respectively, for BL+FGDG compared with NPK (table 4). There were no differences in nutrient concentrations between $\mathrm{BL}$ and $\mathrm{BL}+\mathrm{FGDG}$ or between NPK and NPK+FGDG. In GBS-FGDG plots, nutrient concentration was not different among the three fertilizer treatments. In GBS+FGDG plots, BL fertilization did not affect nutrient concentration compared with NPK. However, BL+FGDG compared with NPK decreased DRP and TP concentrations by $67 \%$ each. Similarly, BL+FGDG compared with BL decreased concentrations of TKN, DRP, and TP by $75 \%$ to $85 \%$. Nutrient concentrations were similar between treatment 1 (NPK and GBS; a standard practice) and treatment 9 $(\mathrm{BL}+\mathrm{FGDG}$ and GBS+FGDG). However, nutrient concentration was $65 \%$ to $80 \%$ less from treatment 9 compared with treatment 4 (BL and-GBS; another standard practice).

Nutrient Load. Figure 5 shows variability within and across treatments for nutrient loads using the original untransformed data. The box plots suggest stronger GBS than fertilizer effects, especially for DRP, TP, and TKN, although a BL (treatments 4, 5, and 6) effect is apparent for DRP and TP when compared with NPK (treatments 1,2, and 3). As in the case of concentration, the box plots for treatment 9 (BL+FGDG plus GBS+FGDG) show that additions of FGDG to both the cropped and GBS areas consistently led to lower loads with the least variance. Nutrient load values within the 4th quartile for BL (treatments 4, 5, and 6) were in greater proportion than those for NPK or BL+FGDG but in this case for only DRP and TP load (note the $\mathrm{y}$-axis in figure 4 is truncatednot all 4th quartile data are shown). Across all treatments, mean nutrient load in the 4th quartile was 5- to 6-fold greater compared with that in the 2nd and 3rd quartile combined (for untransformed data).

Table 3 shows results from analysis of variance for nutrient load while table 4 shows back-transformed LS-means and significance of difference between LS-means of paired treatments based on analysis of LN-transformed data. Treatment had significant effects on loads of $\mathrm{NO}_{3}-\mathrm{N}, \mathrm{DRP}$, and TP while plot slope had significant effect on load of $\mathrm{NO}_{3}-\mathrm{N}$ only. The prerunoff five-day antecedent rainfall + irrigation had significant effect on all nutrient loads. The interval between planting and runoff dates had significant effects on loads of TKN, DRP, and TP only.

Nutrient Load under Different Fertilization Treatments. In treatments fertilized with NPK (treatments 1, 2, and 3), GBS-FGDG compared with -GBS decreased loads for $\mathrm{NO}_{3}-\mathrm{N}$ and $\mathrm{NH}_{4}-\mathrm{N}$ by $\sim 40 \%$ (table 4 ). GBS+FGDG decreased $\mathrm{NO}_{3}-\mathrm{N}$ load by $54 \%$ compared with - GBS. There was no difference for any nutrient load between GBS-FGDG and GBS+FGDG. In treatments fertilized with BL (treatments 4, 5, and 6), GBS-FGDG had no significant effect on nutrient load compared with GBS. However, GBS+FGDG decreased load for $\mathrm{NO}_{3}-\mathrm{N}$ by $56 \%$ compared with - GBS. Similarly, GBS+FGDG decreased load of $\mathrm{NO}_{3}-\mathrm{N}$ by $41 \%$ compared with GBSFGDG. In BL+FGDG plots (treatments 7, 8, and 9), GBS-FGDG decreased $\mathrm{NH}_{4}-\mathrm{N}$ load by $38 \%$ compared with -GBS. GBS+FGDG decreased loads of $\mathrm{NH}_{4}-\mathrm{N}, \mathrm{TKN}, \mathrm{DRP}$, and TP by $55 \%$ to $60 \%$ compared with -GBS. GBS+FGDG compared with GBS-FGDG decreased loads of $\mathrm{NH}_{4}-\mathrm{N}, \mathrm{TKN}, \mathrm{DRP}$, and TP by $35 \%$ to $50 \%$.

Nutrient Load under Different Grass Buffer Strips Treatments. In treatments without GBS (-GBS), BL compared with NPK fertilization had no significant effect on nutrient load (table 4). Fertilization with BL+FGDG reduced $\mathrm{NO}_{3}-\mathrm{N}$ load by $40 \%$ compared with NPK. Nutrient loads were similar between BL+FGDG and BL fertilization. Adding FGDG to NPK or BL did not change nutrient loads. In the GBS-FGDG treatments, fertilizer source had no effect on nutrient load. In the GBS+FGDG treatments, nutrient load was similar between BL and NPK fertilization. In contrast, BL+FGDG decreased loads of $\mathrm{NH}_{4}-\mathrm{N}$, DRP, and TP 45\% to $50 \%$ compared with NPK fertilization for the GBS+FGDG treatments. Similarly, BL+FGDG compared with BL fertilization decreased loads of $\mathrm{NH}_{4}-\mathrm{N}$ and TP by $40 \%$ to $50 \%$ for the GBS+FGDG treatments. Nutrient load from treatment 9 (combined $\mathrm{BL}+\mathrm{FGDG}$ and $\mathrm{GBS}+\mathrm{FGDG})$ was $50 \%$ to $70 \%$ less compared with treatment 1 (NPK 


\section{Figure 5}

Box plots showing variability of nutrient load for (a) dissolved reactive phosphorus (DRP), (b) total phosphorus (TP), (c) nitrate-nitrogen (NO $-\mathrm{N}$ ), (d) ammonium-nitrogen $\left(\mathrm{NH}_{4}-\mathrm{N}\right)$, and (e) total Kjeldahl nitrogen (TKN) by treatment based on the original nontransformed data. Boxes enclose data within the $25^{\text {th }}$ and $75^{\text {th }}$ percentiles. Dotted and sold lines within boxes represent means and medians, respectively. Whiskers represent data at 90 th percentile. Treatment details: $1=$ NPK and $(-G B S) ; 2=$ NPK and (GBS-FGDG); $3=$ NPK and (GBS+FGDG); $4=B L$ and $(-G B S) ; 5=B L$ and $(G B S-F G D G)$; $6=\mathrm{BL}$ and $(\mathrm{GBS}+\mathrm{FGDG}) ; 7=(\mathrm{BL}+\mathrm{FGDG})$ and $(-\mathrm{GBS}) ; 8=(\mathrm{BL}+\mathrm{FGDG})$ and $(\mathrm{GBS}-\mathrm{FGDG}) ; 9=(\mathrm{BL}+\mathrm{FGDG})$ and $(\mathrm{GBS}+\mathrm{FGDG}) ; 10=(\mathrm{NPK}+\mathrm{FGDG})$ and $(-$ GBS). NPK = inorganic fertilizer; $B L=$ broiler litter; FGDG = flue gas desulfurization gypsum. $Y$-axis is truncated. Values not shown in (a) are 51 to 260 for treatments 4 to 6 and 10; in (b), 101 to 358 for treatments 3 to 7 and 10; in (c), 54 for treatment 10; in (d), 82 to 235 for all treatments but 1, 3,5 , and 8; and in (e), 464 to 1,312 for treatments 2, 8, and 10.

(a)

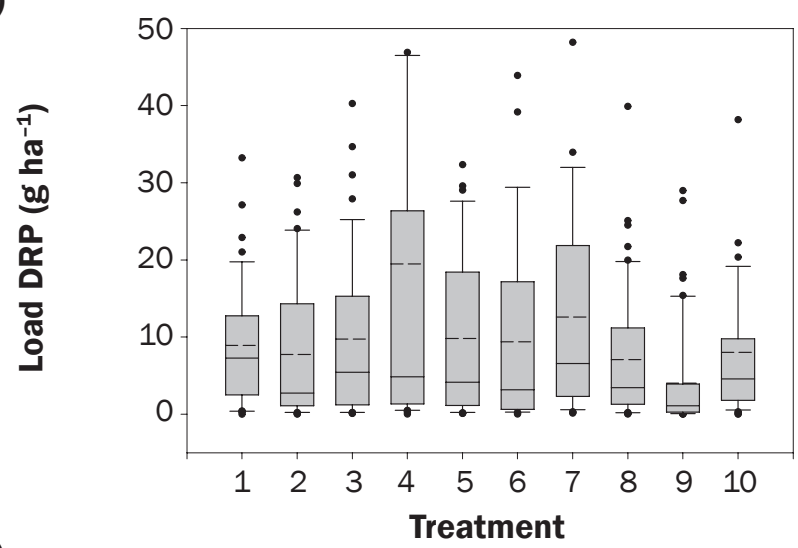

(c)

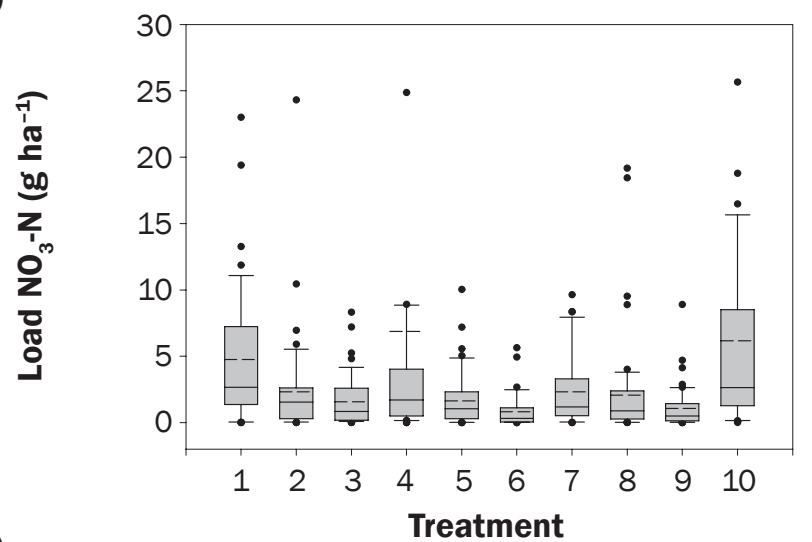

(e)

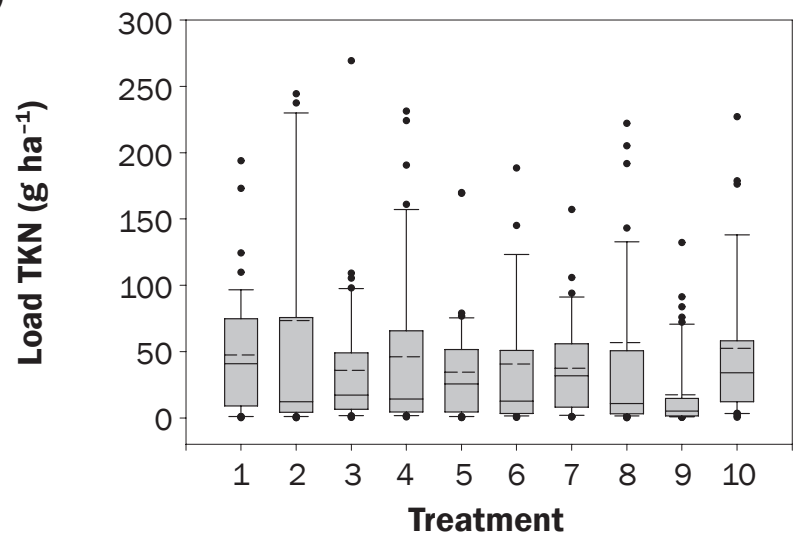

(b)

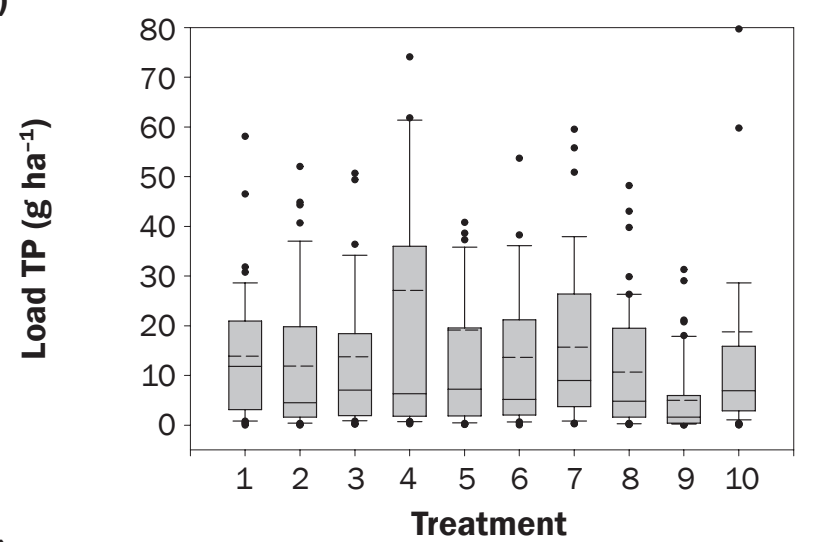

(d)

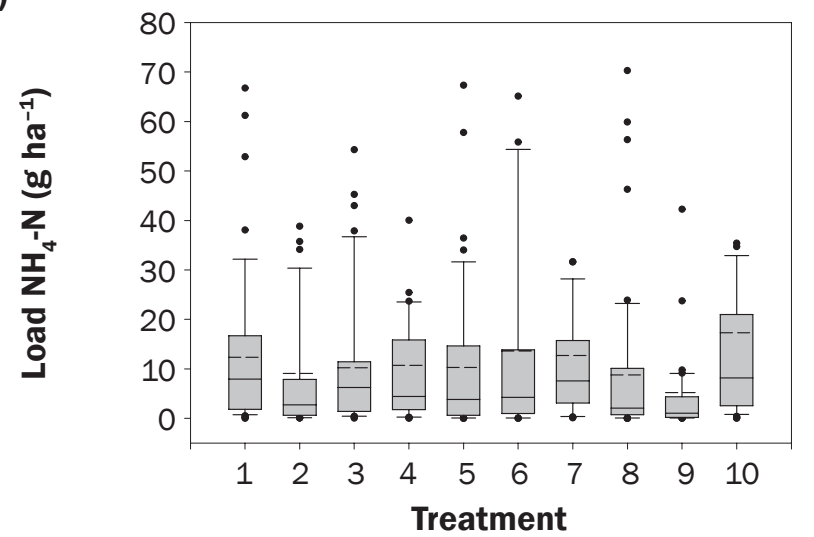

and $-\mathrm{GBS})$ and $40 \%$ to $65 \%$ less compared with treatment 4 (BL and-GBS).

Correlation between Dissolved Reactive Phosphorus and Total Phosphorus. Table
5 shows slope parameters for linear regressions between DRP as the dependent and TP as the independent variables (with the intercept set at zero) for concentration and load of the various treatments. Across all treatments, DRP accounted for $56 \%$ of TP concentration and $70 \%$ of TP load. There was some variation by treatment. For NPK 


\section{Table 5}

Parameters for linear regression for concentration and load between dissolved reactive phosphorus (DRP as dependent variable) and total P (TP as independent variable) by treatment.

\begin{tabular}{|c|c|c|c|c|c|c|}
\hline \multirow{2}{*}{$\begin{array}{l}\text { Treatment } \\
\#\end{array}$} & \multirow{2}{*}{$\begin{array}{l}\text { Plot } \\
\text { fertilizer }\end{array}$} & \multirow[b]{2}{*}{ Buffer arrangement } & \multicolumn{2}{|c|}{$\begin{array}{l}\text { Concentration } \\
\left(\mu \mathrm{g} \mathrm{L}^{-1}\right)\end{array}$} & \multicolumn{2}{|c|}{$\begin{array}{l}\text { Load } \\
\left(\text { g ha }^{-1}\right)\end{array}$} \\
\hline & & & $r^{2}$ & Slope & $r^{2}$ & Slope \\
\hline 1 & NPK & No buffer (-GBS) & 0.863 & 0.629 & 0.776 & 0.670 \\
\hline 2 & NPK & Buffer no gypsum (GBS-FGDG) & 0.978 & 0.689 & 0.904 & 0.626 \\
\hline 3 & NPK & Buffer with gypsum (GBS+FGDG) & 0.982 & 0.843 & 0.927 & 0.757 \\
\hline 4 & $\mathrm{BL}$ & No buffer (-GBS) & 0.713 & 0.631 & 0.897 & 0.790 \\
\hline 5 & $\mathrm{BL}$ & Buffer no gypsum (GBS-FGDG) & 0.892 & 0.467 & 0.923 & 0.748 \\
\hline 6 & $\mathrm{BL}$ & Buffer with gypsum (GBS+FGDG) & 0.945 & 0.573 & 0.838 & 0.620 \\
\hline 7 & $\mathrm{BL}$ & No buffer (-GBS) & 0.967 & 0.691 & 0.900 & 0.799 \\
\hline 8 & $\mathrm{BL}$ & Buffer no gypsum (GBS-FGDG) & 0.833 & 0.319 & 0.816 & 0.642 \\
\hline 9 & $\mathrm{BL}$ & Buffer with gypsum (GBS+FGDG) & 0.732 & 0.711 & 0.938 & 0.854 \\
\hline 10 & NPK & No buffer (-GBS) & 0.741 & 0.590 & 0.937 & 0.575 \\
\hline ALL & ALL & NA & 0.862 & 0.558 & 0.872 & 0.696 \\
\hline
\end{tabular}

Notes: $\mathrm{NPK}=$ inorganic fertilizer. $\mathrm{BL}=$ broiler litter. FGDG = flue gas desulfurization gypsum. $\mathrm{GBS}$ $=$ grass buffer strip. $\mathrm{NA}=$ not applicable. All linear regression models were significant at alpha $\leq$ 0.05 .

fertilization, DRP concentration and load constituted $62 \%$ to $84 \%$ and $62 \%$ to $76 \%$ of TP, respectively. For BL fertilization, DRP accounted for $46 \%$ to $63 \%$ of TP concentration, lowest in GBS-FGDG, and $62 \%$ to $79 \%$ of TP load. For BL+FGDG fertilization, DRP accounted for $31 \%$ to $71 \%$ of TP concentration, lowest in GBS-FGDG, and 64\% to $85 \%$ of TP load.

The BL contribution to reductions in runoff likely arose from organic matter additions improving surface soil physical properties as highlighted in Feng et al. $(2019,2021)$ and studies cited therein, where organic amendments varied with rates as high as $17 \mathrm{Mg} \mathrm{ha}^{-1}$ $\mathrm{y}^{-1}$ in some cases. Feng et al. (2021) reported improved soil aggregate stability, infiltration rate, saturated hydraulic conductivity, and soil water retention and availability for a sandy loam soil under a cotton (Gossypium hirsutum L)-corn-soybean (Glycine max [L.] Merr.) rotation following application of $\mathrm{BL}$ at 7.6 $\mathrm{Mg} \mathrm{ha}{ }^{-1} \mathrm{y}^{-1}$ for five years. Similar results were reported for a fine sandy loam soil under cotton after four years of $\mathrm{BL}$ application at 6.7 $\mathrm{Mg} \mathrm{ha}^{-1} \mathrm{y}^{-1}$ (Feng et al. 2019). Total C content of $\mathrm{BL}$ is variable as shown by reports from Feng et al. (2021) (202 to $232 \mathrm{~kg} \mathrm{Mg}^{-1}$ ) and Sharpley et al. (2020) (mean of $253 \mathrm{~kg}$ $\mathrm{Mg}^{-1}$ from 289 samples in Arkansas). Taking an average total C content of $230 \mathrm{~kg} \mathrm{Mg}^{-1}$, at our annual BL application rate of $13.45 \mathrm{Mg}$ $\mathrm{ha}^{-1}$, we would have added annually approximately 3.4 Mg ha ${ }^{-1}$ of total C under BL.
Several factors contribute to the effectiveness of GBS in reducing nonpoint source pollution from agricultural fields (Proser et al. 2020; Valkama et al. 2019). Proser et al. (2020) list buffer width, ratio of source to buffer area, slope, rainfall and runoff intensity, soil composition and structure, plant community structure, interval from nutrient or pesticide application, and fate and transport properties of nutrients and pesticides as factors that come into play. Surface vegetation, root zone, and subsoil also play important roles in nutrient loss reduction efficacy. Optimizing combinations of the factors indicated above would be expected to provide the greatest benefit. Proser et al. (2020) found that in some instances, buffer widths $<5 \mathrm{~m}$ were similarly efficient as one with $60 \mathrm{~m}$ width. The magnitude and rate of rainfall and of runoff entering a vegetated buffer, along with nutrient concentrations, is an important factor determining GBS effectiveness. A region with lower total rainfall and/or less frequent intense rainfall may achieve the desired nutrient or pesticide reduction efficiency with a narrower width GBS. Habibiandehkordi et al. (2019) noted that GBSs reduce nutrient losses best under diffuse, shallow flow, rather than concentrated flow conditions, and could even be ineffective under the latter flow conditions.

In our case, slope, source area, and GBS width (where present) were similar among the various treatments. Also, the shallow slope and observed flow condition would have resulted in diffuse shallow flow favorable to increasing infiltration. Our treatments, fertilizer source, the presence or absence of GBS, and application of FGDG were the primary factors influencing GBS performance efficacy. Our GBS were well established from over a decade of bermudagrass production that stabilized and improved surface and subsurface physical and hydraulic properties conducive for soil water infiltration and nutrient capture. Tillage of the corn cropped area twice each year (preplanting of corn and rye) would be expected to increase the rate of SOM decomposition and disruption of physical properties favorable to infiltration. Habibiandehkordi et al. (2019) noted that even though GBSs are effective in reducing total and particulate $\mathrm{P}$ in runoff, their effectiveness in reducing dissolved $\mathrm{P}$ long term could be uncertain due to accumulation of legacy P, in which case GBS could become sources of dissolved P. This effect would not have been expected in our study due to the short three-year period of BL application. Overall, our results point to the strong advantage of including GBS \pm FGDG downstream of cropped fields to reduce runoff and nutrient loss for soils in our region.

As indicated in the introduction, previous studies have documented reductions in soil soluble $\mathrm{P}$ after gypsum application. In addition to increased infiltration due to improved soil aggregation and flocculation under FGDG, decreased P concentrations observed in the current study were likely due to enhanced P sorption through the dissolution of the $\mathrm{Ca}$ in the applied FGDG and the precipitation of $\mathrm{Ca}-, \mathrm{Al}-$, and $\mathrm{Fe}-$ phosphates (Havlin et al. 1999; King et al. 2016; Callahan et al. 2002; Cox et al. 2005; Stout et al. 1998). In an incubation study with five contrasting soils, Murphy et al. (2010) compared P reduction potential of lime and gypsum assessed by water extraction. Gypsum application had greater effect decreasing molybdate-reactive P solubility by $14 \%$ to $56 \%$ and organic P by $10 \%$ to $53 \%$ across all soils. The authors note that although often neglected in studies of $\mathrm{P}$ losses, organic $\mathrm{P}$ can be an important fraction in soil solution and P loss. Organic $\mathrm{P}$ can become bio-available and contribute to eutrophication in receiving water bodies. Decreased organic P solubility with liming in two soils and with gypsum in all soils may be due to increased stability of organic matter complexes with increased $\mathrm{Ca}$ concentrations and ionic strength. 
Concentrations for soluble $\mathrm{P}$ we observed were in the range recently reported from other studies involving BL and FGDG such as Endale et al. (2014b), Sheng et al. (2014), Torbert and Watts (2014), and Watts and Torbert (2009). These studies used rainfall simulations conducted immediately or within a few weeks of applying treatments. In one case (Torbert and Watts 2014), two natural rain events that produced runoff occurred before rainfall simulation. Treatments that received BL at $\sim 9$ or $13 \mathrm{Mg} \mathrm{ha}^{-1}$ had soluble $\mathrm{P}$ concentrations in the range 5 to 47 $\mathrm{mg} \mathrm{L}^{-1}$. Treatments that combined these $\mathrm{BL}$ rates with rates of 6 or $9 \mathrm{Mg} \mathrm{ha}^{-1}$ gypsum had soluble $\mathrm{P}$ concertation in the range 1 to $26 \mathrm{mg} \mathrm{L}^{-1}$. In the one study that involved GBS with gypsum (Sheng et al. 2014), soluble $\mathrm{P}$ concentration was reduced by $40 \%$. Concentrations were $9 \mathrm{mg} \mathrm{L}^{-1}$ in the rainfall simulation immediately after treatment application and $4 \mathrm{mg} \mathrm{L}^{-1}$ four weeks later.

\section{Summary and Conclusions}

We evaluated the potential for FGDG to reduce losses of nutrients at the field edge and from GBS located at the down slope field edge for Coastal Plain soils cropped to corn fertilized with NPK or BL. In this first part of a three-phase study, BL and FGDG were applied at rates of $13.45 \mathrm{Mg} \mathrm{ha}^{-1}$ each year. The three phases of the study will track hysteresis of nutrient dynamics in the soil, runoff, and plants from residual sources of $\mathrm{BL}$ and FGDG. Our BL rate during phase-1 would be considered excessive relative to P-Index application rates with a high probability of nutrient loss. The remaining two phases of the project are designed to evaluate legacy implications of the current rates as applications of BL and FGDG are reduced over time.

During phase-1 (this article), runoff quantity and quality data gathered from 29 storms over a 21-month period from May of 2015 through January of 2017, with 17 in 2015 and 11 in 2016, are used to assesses treatment impacts on percentage runoff and concentration and load of $\mathrm{NH}_{4}-\mathrm{N}, \mathrm{NO}_{3}-\mathrm{N}, \mathrm{TKN}$, DRP, and TP. The results showed that edgeof-field runoff and nutrient concentration and load can be significantly reduced under the following conditions.

Runoff:

- In cases of -GBS, fertilizing with BL or $\mathrm{BL}+\mathrm{FGDG}$ instead of NPK can reduce percentage runoff by $50 \%$ to $60 \%$.
- When fertilizing with NPK, GBSFGDG or GBS+FGDG can reduce percentage runoff by $60 \%$ to $70 \%$ compared with -GBS.

- When fertilizing with BL, GBS+FGDG can reduce percentage runoff by $40 \%$ to $60 \%$ compared with -GBS or GBS-FGDG.

Nutrient concentration:

- When fertilizing with NPK, GBSFGDG or GBS+FGDG does not change nutrient concentration.

- When fertilizing with BL, adding GBSFGDG or GBS+FGDG can reduce $\mathrm{NO}_{3}-\mathrm{N}$ concentration by $50 \%$ to $70 \%$ compared with -GBS. In the -GBS, fertilizing with BL or BL+FGDG instead of NPK can increase concentration of DRP and TP by $110 \%$ to $165 \%$.

- When fertilizing with BL+FGDG, GBS-FGDG does not affect nutrient concentration compared with -GBS but GBS+FGDG can reduce concentrations of $\mathrm{NH}_{4}-\mathrm{N}, \mathrm{TKN}, \mathrm{DRP}$, and TP by $65 \%$ to $80 \%$ compared with -GBS, and DRP and TP concentration about $60 \%$ compared with GBS-FGDG.

- When GBS+FGDG are added, fertilization with BL+FGDG instead of NPK can decrease concentrating of DRP or $\mathrm{TP}$ by $65 \%$ to $70 \%$; fertilization with $\mathrm{BL}+\mathrm{FGDG}$ instead of $\mathrm{BL}$ can decrease concentrating of $\mathrm{NH}_{4}-\mathrm{N}$, TKN, DRP, and TP by $75 \%$ to $85 \%$.

Nutrient load:

- When fertilizing with NPK, GBSFGDG or GBS+FGDG versus - GBS can reduce load of $\mathrm{NO}_{3}-\mathrm{N}$ by $35 \%$ to $55 \%$ due to a reduction in runoff; $\mathrm{NH}_{4}-\mathrm{N}$ load can decrease by $40 \%$ for GBS-FGDG versus -GBS.

- When fertilizing with BL only, GBS+FGDG versus -GBS or versus GBS-FGDG can reduce $\mathrm{NO}_{3}-\mathrm{N}$ load $40 \%$ to $60 \%$ due to a reduction in runoff.

- When fertilizing with BL+FGDG, GBS+FGDG can reduce load of $\mathrm{NH}_{4}-\mathrm{N}$, TKN, DRP, and TP by $\sim 60 \%$ compared with -GBS, and $35 \%$ to $50 \%$ compared with GBS-FGDG.

- When GBS+FGDG are included, fertilization with BL+FGDG instead of NPK can reduce loads of $\mathrm{NH}_{4}-\mathrm{N}, \mathrm{DRP}$, and TP by $45 \%$ to $55 \%$; fertilization with $\mathrm{BL}+\mathrm{FGDG}$ instead of $\mathrm{BL}$ can reduce loads of $\mathrm{NH}_{4}-\mathrm{N}$ and TP by $40 \%$ to $50 \%$.
Consistently, combining BL+FGDG with GBS+FGDG was one of the most effective ways for reducing nutrient losses. This treatment reduced nutrient load by $50 \%$ to $70 \%$ compared with NPK fertilization and-GBS. BL+FGDG with GBS+FGDG also reduced nutrient concentration by $65 \%$ to $80 \%$ and nutrient load by $40 \%$ to $65 \%$ compared with BL fertilization and -GBS. Our results point to a simple approach to improving edgeof-field runoff quality in cropping systems of the US Southeast, especially where BL is used as fertilizer source. Further studies conducted at field and watershed scales would be needed to quantify landscape scale benefits of these practices.

\section{Acknowledgements}

This research was a contribution from the Long-Term Agroecosystem Research (LTAR) network. LTAR is supported by the USDA. This work was also supported by the USDA Agricultural Research Service (ARS) National Program 216, Sustainable Agricultural Systems Research. We also acknowledge the financial support from Southern Company (Agreement No. 58-6602-4-224) and Duke Energy (Agreement No. 58-6420-4-001). The authors are grateful for pivotal and competent contribution to the research by John Davis, Bryant Luke, and Bobby Shiver, and significant assistance by Bennett Marshall, Josie McCully, Coby Smith, Lorine Lewis, Ricky Fletcher, Ernest Harris, and Joshua Moore, all with the USDA ARS Southeast Watershed Research Laboratory in Tifton, Georgia. We also acknowledge assistance with field and laboratory work from several students from the University of Georgia, Tifton Campus.

\section{Disclaimer}

Mention of trademark, proprietary product, or vendor does not constitute a guarantee or warranty of the product by the USDA and does not imply approval to the exclusion of other products or vendors that also may be suitable.

\section{References}

Adeli, A., H. Tewolde, K.R. Sistani, and D.E. Rowe. 2007. Effects of broiler litter applied to no-till and tillage cotton on selected soil properties. Soil Science Society of American Journal 71:974-983.

Adeli, A., H. Tewolde, K. Sistani, and D. Rowe. 2010. Comparison of broiler litter and commercial fertilizer at equivalent $\mathrm{N}$ rates on soil properties. Communications in Soil Science and Plant Analysis 41:2432-2447.

American Coal Ash Association. 2021. American Coal Ash Association. Denver, CO: American Coal Ash Association. https://www.acaa-usa.org.

Ashworth, A.J., J.P. Chastain, and P.A. Moore Jr. 2019. Nutrient characteristics of poultry manure and litter. In Animal Manure: Production, Characteristics, Environmental Concerns, and Management. ASA 
Special Publication 67, eds. H.M. Waldrip, P.H. Pagliari, and Z. He, 63-88. Madison, WI: American Society of Agronomy and Soil Science Society of America.

Bosch, D.D., O. Pisani, A.W. Coffin, and T.C. Strickland. 2020. Water quality and land cover in the Coastal plain Little River watershed, Georgia, United States. Journal of Soil and Water Conservation 75(3):263-277. https:// doi.org/10.2489/jswc.75.3.263.

Bosch, D.D., T.L. Potter, T.C. Strickland, and R.K. Hubbard. 2015. Dissolved nitrogen, chloride, and potassium loss from fields in conventional and conservation tillage. Transactions of the ASABE 58(3):1559-1571.

Bosch, D.D., C.C. Truman, T.L. Potter, L.T. West, T.C. Strickland, and R.K. Hubbard. 2012. Tillage and slope position impact on field-scale hydrologic processes in the South Atlantic Coastal Plain. Agricultural Water Management 111:40-52.

Callahan, M.P., P.J.A. Kleinman, A.N. Sharpley, and W.L. Stout. 2002. Assessing the efficacy of alternative phosphorus sorbing soil amendments. Soil Science 167:539-547.

Carpenter, S.R., N.F. Caraco, D.L. Correll, R.W. Howarth, A.N. Sharpley, and V.H. Smith. 1998. Nonpoint pollution of surface waters with phosphorus and nitrogen. Ecological Applications 8:559-568.

Chen, L., and W.A. Dick. 2011. Gypsum as an Agricultural Amendment: General Use Guidelines. Bulletin 945. Columbus, OH: Ohio State University Extension, Ohio State University.

Cox, J.W., J.C.R. Varcoe, D.J. Chittleborough, and J. van Leeuwen. 2005. Using gypsum to reduce phosphorus in runoff from subcatchments in South Australia. Journal of Environmental Quality 34:2118-2128.

Crocker, W. 1922. History of the Use of Agricultural Gypsum. Chicago, IL: Gypsum Industries Association.

Dillaha,T.A., R.B. Reneau, S. Mostaghimi, and D. Lee. 1989. Vegetative filter strips for agricultural nonpoint source pollution control. Transactions of the ASAE 32:513-519.

Dorioz, J.M., D. Wang, J. Poulenard, and D. Treéisan. 2006. The effect of grass buffer strips on phosphorus dynamics - A critical review and synthesis as a basis for application in agricultural landscapes in France. Agriculture, Ecosystems and Environment 117:4-21.

Eden, M., H.H. Gerke, and S. Houot. 2017. Organic waste recycling in agriculture and related effects on soil water retention and plant available water: A review. Agronomy of Sustainable Development 37. https://doi. org/10.1007/s13593-017-0419-9.

Edmeades, D.C. 2003. The long-term effects of manures and fertilizers on soil productivity and quality-A review. Nutrient Cycling in Agroecosystems 66:165-180.

Endale, D.M., D.D. Bosch, T.L. Potter, and T.C. Strickland. 2014a. Sediment loss and runoff from cropland in a Southeast Atlantic Coastal Plain landscape. Transactions of the ASABE 57(6):1611-1626.

Endale, D.M., H.H. Schomberg, D.S. Fisher, D.H. Franklin, and M. Jenkins. 2014b. Flue gas desulfurization gypsum:
Implication for runoff and nutrient losses associated with broiler litter use on pastures on Ultisols. Journal of Environmental Quality 43:281-289.

Endale, D.M., H.H. Schomberg, M.B. Jenkins, D.H. Franklin, and D.S. Fisher. 2010. Management implications of conservation tillage and poultry litter use for Southern USA cropping Systems. Nutrient Cycling in Agroecosystems 88:299-313.

EPRI (Electric Power Research Institute). 2006. A Review of Agricultural and Other Land Application Uses of Flue Gas Desulfurization Products. 1010385. Palo Alto, CA: Electric Power Research Institute.

EPRI. 2011. Composition and Leaching of FGD Gypsum and Mined Gypsum. 1022146. Palo Alto, CA: Electric Power Research Institute.

Feng, G., A. Adeli, J. Read, J. McCarty, and J. Jenkins. 2019. Consequences of pelletized poultry litter applications on soil physical and hydraulic properties in reduced tillage, continuous cotton system. Soil \& Tillage Research 194(2019):104309. https://doi.org/10.1016/j. still.2019.104309.

Feng, G., H. Tewolde, B. Zhang, N. Buehring, and A. Adeli. 2021. Soil physical and hydrologic properties as affected by a five-year history of poultry litter applied to a cotton-corn-soybean rotation system. Soil Society of American Journal 85(3):800-813. https://doi. org/10.1002/saj2.20224.

Franklin, D.H., M.L. Cabrera, J.L. Steiner, D.M. Endale, and W.P. Miller. 2001. Evaluation of percent flow captured by a small in-field runoff collector. Transactions of the ASAE 44(3):551-554.

Good, K.D., and J.M. VanBriesen. 2019. Coal-fired power plant wet flue gas desulfurization bromide discharges to U.S. watersheds and their contributions to drinking water sources. Environmental Science Technology 53:213-223.

Habibiandehkordi, R., D.A. Lobb, P.N. Owens, and D.N. Flaten. 2019. Effectiveness of vegetated buffer strips in controlling legacy phosphorus exports from agricultural Land. Journal of Environmental Quality 48:314-321.

Havlin, J.L., J.D. Beaton, S.L. Tisdale, and W.L. Nelson. 1999. Soil Fertility and Fertilizers: An Introduction to Nutrient Management, 6th edition. Upper Saddle River, NJ: Prentice Hall.

He, Z., D.M. Endale, H.H. Schomberg, and M.B. Jenkins. 2009. Total phosphorus, zinc, copper, and manganese concentrations in Cecil soil through 10 years of poultry litter application. Soil Science 174:687-695.

Hou, Q.H., A.Z. Ma, D. Lv, Z.H. Bai, X.L. Zhuang, and G.Q. Zhuang. 2014. Impacts of different long-term fertilization regimes on the bioavailability of arsenic in soil: Integrating chemical approach with Escherichia coli ars $R$ ::luc-based biosensor. Applied Microbiology and Biotechnology 98:6137-6146.

Kairies, C.L., K.T. Schroeber, and C.R. Cardone 2006. Mercury in gypsum produced from flue gas desulfurization. Fuel 85:2530-2536.
King, K.W., M.R. Williams, W.A. Dick, and G.A. LaBarge. 2016. Decreasing phosphorus loss in tile-drained landscapes using flue gas desulfurization gypsum. Journal of Environmental Quality 45:1722-1730.

Kingery,W.L., C.W.Wood, D.P.Delany,J.C.Williams, and G.L. Mullins. 1994. Impact of long-term land application of broiler litter on environmentally related soil properties. Journal of Environmental Quality 23:139-147.

Koralegedara, N.H., P.X. Pinto, D.D. Dionysiou, and S.R. Al-Abed. 2019. Recent advances in flue gas desulfurization gypsum processes and applications-A review. Journal of Environmental Management 251(2019):109572. https://doi.org/10.1016/j. jenvman.2019.109572.

Langdale, G.W., W.C. Mills, and A.W.Thomas. 1992. Use of conservation tillage to retard erosive effects. Journal of Soil and Water Conservation 47(3):257-290.

Lee, D. (ed.). 2012. A guide to Corn Production in Georgia 2013. Miscellaneous Publication CSS 01-2012. Athens, GA: College of Agricultural and Environmental Sciences, University of Georgia.

Magette, W.L., R.B. Brinsfield, R.E. Palmer, and J.D. Wood. 1989. Nutrient and sediment removal by vegetated filter strips. Transactions of the ASAE 32:663-667.

Miller, W.P, H.F. Perkins, D.E. Radcliffe, M.E. Sumner, J. Scifres, J. Kim, and S.C. Chang. 1998. Use of Gypsum to Improve Physical Properties and Water Relations in Southeastern Soils. Publication No. 01-020-082 Athens, GA: University of Georgia Research Foundation.

Mitchell, C.C., and S. Tu. 2005. Long-term evaluation of poultry litter as a source of nitrogen for cotton and corn. Agronomy Journal 97:399-407.

Moore, P.A., T.C. Daniel, A.N. Sharpley, and C.W. Wood. 1995. Poultry manure management: Environmentally sound options. Journal of Soil Water Conservation 50(3):321-327.

Norton, L.D. 2008. Gypsum soil amendment as a management practice in conservation tillage to improve water quality and tillage. Journal of Soil and Water Conservation 63(2):46A-48A. https://doi.org/10.2489/ jswc.63.2.46A.

Norton, L.D., and K.M. Dontsova. 1998. Use of soil amendments to prevent soil surface sealing and control erosion. Advance in Geoecology 31:581-587.

Pisani, O., D. Liebert, D.D. Bosch, A.W. Coffin, D.M. Endale, T.L. Potter, and T.C. Strickland. 2020. Element losses from fields in conventional and conservation tillage in the Atlantic Coastal Plain, Georgia, United States. Journal of Soil and Water Conservation 75(3):376-386. https://doi.org/10.2489/jswc.75.3.376.

Ritz, C.W., and W.C. Merka. 2013. Maximizing Poultry Manure Use Through Nutrient Management Planning. UGA Cooperative Extension Bull. 1245. Athens, GA: College of Agriculture and Environmental Sciences, University of Georgia.

SAS Institute Inc. 2016. SAS/STAT 14.3 User's Guide. Cary, NC: SAS Institute Inc. 
SAS Institute Inc. 2017. SAS Enterprise Gide 8.1: User's Guide. Cary, NC: SAS Institute Inc.

Schomberg, H.H., D.M. Endale, M.B. Jenkins, R.L. Chaney, and D.H. Franklin. 2018. Metals in soil and runoff from a piedmont hay field amended with broiler litter and flue gas desulfurization gypsum. Journal of Environmental Quality 47:326-335.

Schomberg, H.H., D.M. Endale, M.B. Jenkins, R.R. Sharpe, D.S. Fisher, M.L. Cabrera, and D.V. McCracken. 2009. Soil test nutrient changes induced by poultry litter under conventional tillage and no-tillage. Soil Science Society of America Journal 73:154-163.

Shainberg, I., M.E. Sumner, W.P. Miller, M.P.W. Farina, M.A. Pavan, and M.V. Fey. 1989. Use of gypsum on soils. A review. Advances in Soil Science 9:1-111.

Sharpley, A., P.C. Klienman, C. Baffaut, D. Beegle, C. Bolster, A. Collick, Z. Easton, J. Lory, N. Nelson, D. Osmond, D. Radcliffe, T. Veith, and J. Weld. 2017. Evaluation of phosphorus site assessment tools: Lessons from the USA. Journal of Environmental Quality 46:1250-1256.

Sharpley, A., N. Slaton, T. Tabler Jr., K. VanDevender, M. Daniels, F. Jones, and T. Daniel. 2020. Nutrient analysis of poultry litter. Bulletin FSA9529. Fayetteville, AK: Division of Agriculture Research \& Extension, University of Arkansas.

Sistani, K.R., G.E. Brink, A. Adeli, H. Tewolde, and D.E. Rowe. 2004. Year-round soil nutrient dynamics from broiler litter application to bermudagrass. Agronomy Journal 96:525-530.

Southern Company. 2017. 2017 Water Action Report. Atlanta, GA: Southern Company.

Southern Company. 2018. Planning for a Low-Carbon Future. Atlanta, GA: Southern Company.

Stout, W.L., A.N. Sharpley, and H.B. Pionke. 1998. Reducing soil phosphorus solubility with coal combustion by-products. Journal of Environmental Quality 27:111-118

Strickland, T.C., B.T. Scully, R.K. Hubbard, D.G. Sullivan, Z. Abdo, M.R. Savabi, R.D. Lee, D.M. Olson, and G.L. Hawkins. 2015. Effect of conservation practices on soil carbon and nitrogen accretion and crop yield in a corn production system in the southeastern Coastal Plain, United States. Journal of Soil and Water Conservation 70(3):170-181. https://doi.org/10.2489/jswc.70.3.170.

Stutter, M.I., W.J. Chardon, and B. Kronvang. 2012. Riparian buffer strips as a multifunctional management tool in agricultural landscapes: Introduction. Journal of Environmental Quality 41:297-303.

Tewolde, H., K.R. Sistani, and D.E. Rowe. 2005. Broiler litter as a micronutrient source for cotton: Concentration in plant parts. Journal of Environmental Quality 34:1697-1706.

Torbert, H.A., and D.B. Watts. 2014. Impact of flue gas desulfurization gypsum application on water quality in a Coastal Plain soil. Journal of Environmental Quality 43:273-280.
UF-IFAS Analytical Services Laboratories. 2016. Comprehensive Quality Assurance plan for University of Florida, Institute of Food and Agricultural Sciences, Analytical Service Laboratories. Gainesville, FL: Institute of Food and Agricultural Sciences, University of Florida. USDA NASS (National Agricultural Statistics Service). 2019. Poultry Production and Value. Final Estimates 20132018. Statistical Bulletin No. 1061. Washington, DC: USDA NASS.

USDA NRCS (Natural Resources Conservation Service). 1999. The National Conservation Buffer Initiative. Washington, DC: USDA NRCS.

USDA NRCS. 2021. Web Soil Survey. Washington, DC: USDA NRCS. websoilsurvey.sc.egov.usda.gov.

Valkama, E., K. Usva, M. Saarinen, and J. Uusi-Kämppä. 2019. A Meta-analysis on nitrogen retention by buffer zones. Journal of Environmental Quality 48:270-279.

Wallace, A. 1994. Use of gypsum on soil where needed can make agriculture more sustainable. Communication in Soil Science and Plant Analysis 25:109-116.

Watts, D.B., and W.A. Dick. 2014. Sustainable uses of FGD gypsum in agricultural systems: Introduction. Journal of Environmental Quality 43:246-252.

Watts, D.B., and H.A. Torbert. 2009. Impact of gypsum applied to buffer strips on reducing soluble $\mathrm{P}$ in surface water runoff. Journal of Environmental Quality 38:1511-1517.

Watts, D.B., and H.A. Torbert. 2016. Influence of flue gas desulfurization gypsum on reducing soluble phosphorus in successive runoff events from a coastal plain bermudagrass pasture. Journal of Environmental Quality 45:1071-1079.

Watts, D.B., H.A. Torbert, S.A. Prior, and G. Huluka. 2010. Long-term tillage and poultry litter impacts soil carbon and nitrogen mineralization and fertility. Soil Science Society of American Journal 74(4):1239-1247.

West, L.T., F.H. Beinroth, M.E. Sumner, and B.T. Kang. 1997. Ultisols: Characteristics and impacts on society. Advances in Agronomy 63:179-236.

Zhang, H., G.V. Johnson, and M. Fram. 2002. Managing phosphorus from animal manure. F-2249. Stillwater, OK: Division of Agricultural Sciences and Natural Resources, Oklahoma State University. http:// poultrywaste.okstate.edu/files/f-2249web.pdf. 